\section{Three-Dimensional Lanthanide-Organic Frameworks Based on Di-, Tetra-, and Hexameric Clusters}

\author{
Fa-Nian Shi, Luís Cunha-Silva, ${ }^{\dagger}$ Tito Trindade, Filipe A. Almeida Paz, ${ }^{*}$ and João Rocha* \\ Department of Chemistry, CICECO, University of Aveiro, 3810-193 Aveiro, Portugal
}

ABSTRACT: Three-dimensional lanthanide-organic frameworks formulated as $\left(\mathrm{CH}_{3}\right)_{2} \mathrm{NH}_{2}\left[\mathrm{Ln}(\text { pydc })_{2}\right] \cdot 1 / 2 \mathrm{H}_{2} \mathrm{O}\left[\mathrm{Ln}^{3+}=\mathrm{Eu}^{3+}(\mathbf{1 a})\right.$ or $\mathrm{Er}^{3+}(\mathbf{1 b})$; pydc ${ }^{2-}$ corresponds to the diprotonated residue of 2,5-pyridinedicarboxylic acid $\left(\mathrm{H}_{2}\right.$ pydc) $],\left[\mathrm{Er}_{4}(\mathrm{OH})_{4}(\mathrm{pydc})_{4}\left(\mathrm{H}_{2} \mathrm{O}\right)_{3}\right] \cdot \mathrm{H}_{2} \mathrm{O}$ (2), and $\left[\mathrm{Pr}_{2}^{\mathrm{III}} \mathrm{Pr}^{\mathrm{IV}}{ }_{1.25} \mathrm{O}(\mathrm{OH})_{3}(\mathrm{pydc})_{3}\right]$ (3) have been isolated from typical solvothermal (1a and $\mathbf{1 b}$ in $N, N$-dimethylformamide DMF) and hydrothermal (2 and 3) syntheses. Materials were characterized in the solid state using single-crystal X-ray diffraction, thermogravimetric analysis, vibrational spectroscopy (FT-IR and FT-Raman), electron microscopy, and CHN elemental analysis. While synthesis in DMF promotes the formation of centrosymmetric dimeric units, which act as building blocks in the construction of anionic ${ }_{\infty}^{3}\left\{\left[\mathrm{Ln}(\mathrm{pydc})_{2}\right]^{-}\right\}$frameworks having the channels filled by the charge-balancing $\left(\mathrm{CH}_{3}\right)_{2} \mathrm{NH}_{2}{ }^{+}$cations generated in situ by the solvolysis of DMF, the use of water as the solvent medium promotes clustering of the lanthanide centers: structures of $\mathbf{2}$ and $\mathbf{3}$ contain instead tetrameric $\left[\mathrm{Er}_{4}\left(\mu_{3}-\mathrm{OH}\right)_{4}\right]^{8+}$ and hexameric $\operatorname{Pr}_{6}\left(\mu_{3}-\mathrm{O}\right)_{2}\left(\mu_{3}-\mathrm{OH}\right)_{6}$ clusters which act as the building blocks of the networks, and are bridged by the $\mathrm{H}_{2-x}$ pydc $^{x-}$ residues. It is demonstrated that this modular approach is reflected in the topological nature of the materials inducing 4-, 8-, and 14-connected uninodal networks (the nodes being the centers of gravity of the clusters) with topologies identical to those of diamond (family 1), and framework types bct (for 2) and bcu-x (for 3), respectively. The thermogravimetric studies of compound $\mathbf{3}$ further reveal a significant weight increase between ambient temperature and $450{ }^{\circ} \mathrm{C}$ with this being correlated with the uptake of oxygen from the surrounding environment by the praseodymium oxide inorganic core.

\section{Introduction}

Multidimensional metal-organic frameworks (MOFs) remain a worldwide topical area of research because a careful selection of the inorganic and organic building components (known as primary building units, PBUs), in combination with a judicious adjustment of the synthetic conditions, can lead to an almost endless number of new structural architectures with fascinating framework topologies. ${ }^{1-3}$ Strongly related with their structural features, MOFs find many potential industrial applications in catalysis, ${ }^{4}$ gas storage and separation, ${ }^{5}$ guest exchange, ${ }^{6}$ or even sensors based on optical or magnetic properties. ${ }^{7}$ Compared to conventional framework-type inorganic materials such as zeolites and transition-metal or lanthanide silicates, ${ }^{8} \mathrm{MOF}$ constitute a new class of materials that are more susceptible to rational design. ${ }^{9}$ Indeed, the use of a typical bottom-up synthetic approach based on the rigid building block concept, also successfully employed for inorganic frameworks, ${ }^{10}$ allows the overcoming of a number of experimental limitations, ${ }^{11}$ in particular for lanthanide centers (lanthanide-organic frameworks, LnOFs) which have intrinsic variable and high coordination numbers, closely associated with flexible coordination environments and supramolecular isomerism. ${ }^{12}$

As a continuation of our efforts toward the isolation of novel MOFs, in particular LnOFs, ${ }^{13-15}$ we are interested in the use of bridging organic ligands based on pyridine derivatives with substitutent carboxylic acid groups. ${ }^{13,15}$ 2,5-Pyridinedicarboxylic acid $\left(\mathrm{H}_{2}\right.$ pydc $)$ shares, on the one hand, striking similarities with the widely employed terephthalic acid ligand ${ }^{16}$ and, on the other, it is known to form framework-type materials with either lanthanides and $d$-block transition metal cations. ${ }^{17}$ Its potential use as a bridging ligand has also been recently explored by us

* To whom correspondence should be addressed. E-mail: filipe.paz@ua.pt (F.A.A.P.); rocha@ua.pt (J.R.). Fax: (+351) 234 401470. Phone: (+351) 234 401418.

† Present address: Centro de Química Estrutural, Instituto Superior Técnico, Technical University of Lisbon, Av Rovisco Pais, 1049-001 Lisbon, Portugal. in the isolation of novel photoluminescent $\mathrm{LnOFs},\left[\mathrm{Ln}_{2}(\text { pydc })_{2^{-}}\right.$ $\left.(1,4-\mathrm{pda})\left(\mathrm{H}_{2} \mathrm{O}\right)_{2}\right]\left(\mathrm{Ln}^{3+}=\mathrm{Eu}^{3+}, \mathrm{Tb}^{3+}, \mathrm{Er}^{3+} ; 1,4-\mathrm{H}_{2} \mathrm{pda}=1,4-\right.$ phenylenediacetic acid]. ${ }^{13}$ Here we wish to describe a series of modular three-dimensional (3D) materials obtained from the self-assembly of lanthanide centers with $\mathrm{H}_{2-x}$ pydc ${ }^{x-}$ residues: $\left(\mathrm{CH}_{3}\right)_{2} \mathrm{NH}_{2}\left[\mathrm{Ln}(\text { pydc })_{2}\right] \cdot 1 / 2 \mathrm{H}_{2} \mathrm{O}$ [where $\left(\mathrm{CH}_{3}\right)_{2} \mathrm{NH}_{2}{ }^{+}$ is the dimethylamonium cation; $\mathrm{Ln}^{3+}=\mathrm{Eu}^{3+}$ (1a) or $\mathrm{Er}^{3+}$ (1b)], $\left[\mathrm{Er}_{4}(\mathrm{OH})_{4}(\mathrm{pydc})_{4}\left(\mathrm{H}_{2} \mathrm{O}\right)_{3}\right] \cdot \mathrm{H}_{2} \mathrm{O}(\mathbf{2})$ and $\left[\mathrm{Pr}^{\mathrm{III}}{ }_{2} \mathrm{Pr}^{\mathrm{IV}}{ }_{1.25} \mathrm{O}-\right.$ $\left.(\mathrm{OH})_{3}(\text { pydc })_{3}\right](3)$. A modification of the synthetic conditions from solvothermal (family 1) to hydrothermal (compounds $\mathbf{2}$ and $\mathbf{3}$ ), and the composition of the initial reactive mixtures, seem to promote clustering of the lanthanide centers leading to the formation of tetrameric $\left[\mathrm{Er}_{4}\left(\mu_{3}-\mathrm{OH}\right)_{4}\right]^{8+}$ (in 2) and unprecedented hexameric $\operatorname{IP}_{6}\left(\mu_{3}-\mathrm{O}\right)_{2}\left(\mu_{3}-\mathrm{OH}\right)_{6} \mid$ (in 3) clusters which play the role of robust inorganic building blocks in the construction of the LnOFs.

\section{Experimental Section}

General Instrumentation. FT-IR spectra were collected from $\mathrm{KBr}$ pellets (Aldrich 99\%+, FT-IR grade) on a Mattson 7000 FT-IR spectrometer. FT-Raman spectra (range $4000-100 \mathrm{~cm}^{-1}$ ) were recorded on a Bruker RFS 100 spectrometer with a Nd:YAG coherent laser $(\lambda$ $=1064 \mathrm{~nm})$.

Elemental analyses for $\mathrm{C}, \mathrm{N}$, and $\mathrm{H}$ were performed with a CHNS932 elemental analyzer at the Microanalysis Laboratory at the Department of Chemistry, University of Aveiro.

Thermogravimetric analyses (TGA) were carried out using a Shimadzu TGA 50 under air, from room temperature to $c a .700{ }^{\circ} \mathrm{C}$, with a heating rate of $5{ }^{\circ} \mathrm{C} / \mathrm{min}$.

Scanning electron microscopy (SEM) and energy dispersive analysis of X-ray spectroscopy (EDS) were performed using a Hitachi S-4100 field emission gun tungsten filament instrument working at $25 \mathrm{kV}$.

Synthesis. Starting chemicals were readily available from commercial sources and used as received without further purification: 2,5pyridinedicarboxylic acid $\left(\mathrm{H}_{2}\right.$ pydc, $\mathrm{C}_{7} \mathrm{H}_{5} \mathrm{NO}_{4}$, purum $\geq 98 \%$, Fluka), $N, N$-dimethylformamide (DMF, $\mathrm{C}_{3} \mathrm{H}_{7} \mathrm{NO}, 99 \%$, Aldrich), monophenylbis(phosphonic acid) $\left(\mathrm{H}_{4} \mathrm{mpbp}, \mathrm{C}_{6} \mathrm{H}_{8} \mathrm{O}_{6} \mathrm{P}_{2}, \geq 95 \%\right.$, Epsilon Chimie), lanthanides (III) chloride hydrates $\left(\mathrm{PrCl}_{3} \cdot 6 \mathrm{H}_{2} \mathrm{O}, \mathrm{EuCl}_{3} \cdot 6 \mathrm{H}_{2} \mathrm{O}\right.$, and $\mathrm{ErCl}_{3} \cdot 6 \mathrm{H}_{2} \mathrm{O} \geq 99.9 \%$ Aldrich). 
Solvothermal Synthesis of $\left(\mathrm{CH}_{3}\right)_{2} \mathrm{NH}_{2}\left[\mathrm{Ln}(\text { pydc })_{2}\right] \cdot \mathbf{1} / \mathbf{2} \mathrm{H}_{2} \mathrm{O}$, [ $\mathrm{Ln}$ $=$ Eu, (1a) and $\mathbf{E r}(\mathbf{1 b})]$. A mixture of $0.160 \mathrm{~g}$ of $\mathrm{H}_{2}$ pydc and 0.120 $\mathrm{g}$ of $\mathrm{EuCl}_{3} \cdot 6 \mathrm{H}_{2} \mathrm{O}$ in $10.0 \mathrm{~g}$ of DMF (molar ratio of 2.1: 1.0: 418, respectively) was stirred to homogeneity at ambient temperature for about $30 \mathrm{~min}$, and then sealed inside a stainless steel autoclave ( $\mathrm{ca} .40$ $\mathrm{mL}$ of internal volume) which was placed inside a preheated oven at $150{ }^{\circ} \mathrm{C}$ for 3 days. The isolated product was solely composed of single crystals of $1 \mathrm{a}\left(0.120 \mathrm{~g}\right.$, yield of $c a .69 \%$ based on $\left.\mathrm{EuCl}_{3} \cdot 6 \mathrm{H}_{2} \mathrm{O}\right)$. The synthesis of compound $\mathbf{1 b}$ followed an identical experimental procedure but using instead $0.130 \mathrm{~g}$ of $\mathrm{ErCl}_{3} \cdot 6 \mathrm{H}_{2} \mathrm{O}$ (molar ratio of reactive mixture of 2.8: 1.0: 402, respectively), with the final product being isolated with a yield of $c a$. $70 \%\left(0.150 \mathrm{~g}\right.$, based on $\left.\mathrm{ErCl}_{3} \cdot 6 \mathrm{H}_{2} \mathrm{O}\right)$.

Elemental Analysis. Calcd (\%) for $\left(\mathrm{CH}_{3}\right)_{2} \mathrm{NH}_{2}\left[\mathrm{Eu}(\text { pydc })_{2}\right] \cdot 1 / 2 \mathrm{H}_{2} \mathrm{O}$ $(\mathrm{MW}=2149.08)$ : C 35.77, N 7.82, H 2.81; Found: C 35.54, N 8.39, $\mathrm{H}$ 3.39. Calcd (\%) for $\left(\mathrm{CH}_{3}\right)_{2} \mathrm{NH}_{2}\left[\mathrm{Er}(\mathrm{pydc})_{2}\right] \cdot 1 / 2 \mathrm{H}_{2} \mathrm{O}(\mathrm{MW}=2210.28)$ : C 34.79, N 7.60, H 2.74; Found: C 35.11, N 8.78, H 3.17.

Selected FT-IR (KBr Pellets) and FT-Raman Main Bands (Inside the Parenthesis in Italics) (in $\left.\mathrm{cm}^{-1}\right)$. For (1a): $3417 \mathrm{w} / \mathrm{br}(3115 \mathrm{~m}, 3058$ $w, 3018 w, 2963 \mathrm{~m}), 2785 \mathrm{w}(2851 \mathrm{w}, 2802 \mathrm{w}), 2480 \mathrm{w}, 1671 \mathrm{~s}(1660$ $w), 1606 \mathrm{~s}(1605 s, 1565 w), 1481 \mathrm{~m}(1428 s), 1423 \mathrm{~s}, 1394 \mathrm{~s}(1382$ $w), 1358 \mathrm{~s}(1342 w), 1285 \mathrm{~m}, 1265 \mathrm{~m},(1287 w, 1261 w), 1177 \mathrm{w}$ $(1149 \mathrm{~m}), 1109 \mathrm{w}(1109 \mathrm{w}), 1038 \mathrm{~m}(1023 \mathrm{w}), 950 \mathrm{w}, 884 \mathrm{w}, 865 \mathrm{w}$ $(869 \mathrm{~m}), 825 \mathrm{~s}(822 \mathrm{w}), 767 \mathrm{~m}(725 \mathrm{w}), 696 \mathrm{w}, 652 \mathrm{w}(653 \mathrm{~m}), 594 \mathrm{w}$, $508 \mathrm{~m}(510$ w). For 1b: 3431 w/br 3036 w (3106 m, $3066 \mathrm{~m}, 3013$ w), $3006 \mathrm{w}, 2932 \mathrm{w}(2963 \mathrm{~m}, 2883 \mathrm{~m}), 2793 \mathrm{w}(2762 \mathrm{w}), 2487 \mathrm{w}, 1685 \mathrm{~s}$ (1652w), $1616 \mathrm{~s}(1605 \mathrm{~s}, 1565 \mathrm{w}), 1481 \mathrm{~m}(1484 w, 1463 w), 1431 \mathrm{~s}$ (1428 s), $1385 \mathrm{~s}(1382 w), 1358 \mathrm{~s}, 1342 \mathrm{~s}(1342 w), 1284 \mathrm{~m}(1288 w)$, $1271 \mathrm{w}(1261 \mathrm{w}), 1175 \mathrm{~m}(1180 \mathrm{w}, 1150 \mathrm{~m}), 1104 \mathrm{~m}(1109 w), 1085 \mathrm{~m}$, $1038 \mathrm{~s}, 950 \mathrm{w}, 887 \mathrm{w}, 867 \mathrm{w},(869 \mathrm{~m}), 827 \mathrm{~s}(822 \mathrm{w}), 775 \mathrm{~s}(725 \mathrm{w})$, $702 \mathrm{~m}, 652 \mathrm{w}(653 \mathrm{~m}), 600 \mathrm{w}, 505 \mathrm{~m}(518 \mathrm{w})$.

Thermogravimetric analysis (TGA) data (weight losses in \%). For 1a: $25-200{ }^{\circ} \mathrm{C}-2.5 \%, 200-385{ }^{\circ} \mathrm{C}-20.4 \%, 385-500-36.9 \%$, $500-600{ }^{\circ} \mathrm{C}-7.0 \%, 600-700{ }^{\circ} \mathrm{C}-1.8 \%$. For $1 \mathrm{~b}: 25-200{ }^{\circ} \mathrm{C}-2.1 \%$, $200-391{ }^{\circ} \mathrm{C}-19.4 \%, 391-600{ }^{\circ} \mathrm{C}-43.8 \%$.

Hydrothermal Synthesis of $\left[\mathrm{Er}_{4}(\mathrm{OH})_{4}(\text { pydc })_{4}\left(\mathrm{H}_{2} \mathrm{O}\right)_{3}\right] \cdot \mathrm{H}_{2} \mathrm{O}$ (2). A mixture containing $0.180 \mathrm{~g}$ of $\mathrm{H}_{2}$ pydc, $0.410 \mathrm{~g}$ of $\mathrm{ErCl}_{3} \cdot 6 \mathrm{H}_{2} \mathrm{O}$, and $0.120 \mathrm{~g}$ of $\mathrm{NaOH}$ in $c a .15 \mathrm{~g}$ of distilled water was stirred through roughly to homogeneity at ambient temperature for about $30 \mathrm{~min}$. The resulting suspension, with a molar ratio of 1.0:1.0:2.8:779, respectively, was transferred to a stainless steel reaction vessel ( $c a .40 \mathrm{~mL}$ of internal volume), which was sealed and placed inside a preheated oven at 180 ${ }^{\circ} \mathrm{C}$. The reaction took place over a period of 3 days, after which the product was isolated from the autoclave contents and washed by sonication to yield block single crystals $(0.22 \mathrm{~g}$, yield of $\mathrm{ca}$. $56 \%$ based on $\mathrm{ErCl}_{3} \cdot 6 \mathrm{H}_{2} \mathrm{O}$ ). Elemental analysis: Calcd (\%) for $\mathrm{C}_{28} \mathrm{H}_{24} \mathrm{Er}_{4} \mathrm{~N}_{4} \mathrm{O}_{24}$ $(\mathrm{MW}=1469.55)$ : C 22.86, N 3.81, H 1.63; Found: C 21.94, N 3.88, $\mathrm{H} 1.51$.

Selected FT-IR (KBr Pellets) and FT-Raman Main Bands (Inside the Parenthesis in Italics) (in $\mathrm{cm}^{-1}$ ). $3405 \mathrm{~m}, 3238 \mathrm{~m}, 3087 \mathrm{w}(3185$ $w, 3146 w, 3084 m, 3067 w, 3053 w), 1614 \mathrm{~s}, 1589 \mathrm{~s}(1597 \mathrm{~s}), 1561 \mathrm{~s}$ $(1565 w), 1481 \mathrm{w}(1485 w), 1415 \mathrm{~m}(1428 s), 1380 \mathrm{~s}, 1350 \mathrm{~s}, 1285 \mathrm{~m}$ $(1287 w, 1270 w), 1169 \mathrm{w}(1179 w, 1150 \mathrm{~m}), 1104 \mathrm{w}(1109 w), 1038 \mathrm{w}$, $942 \mathrm{w}, 884 \mathrm{w}(877 \mathrm{~m}), 819 \mathrm{~m}(829 \mathrm{w}), 761 \mathrm{~m}, 696 \mathrm{w}, 652 \mathrm{w}(653 \mathrm{~m})$, $578 \mathrm{w}(582 w), 528 \mathrm{~m}(522 w)$.

Thermogravimetric analysis (TGA) data (weight losses in \%): $160-400{ }^{\circ} \mathrm{C}-5.2 \%, 400-455{ }^{\circ} \mathrm{C}-1.7 \%, 455-700{ }^{\circ} \mathrm{C}-41.8 \%$.

Hydrothermal Synthesis of $\left[\mathrm{Pr}^{\mathrm{III}}{ }_{2} \mathrm{Pr}^{\mathrm{IV}}{ }_{1.25} \mathrm{O}(\mathrm{OH})_{3}(\mathrm{pydc})_{3}\right]$ (3). A mixture of $0.060 \mathrm{~g}$ of $\mathrm{H}_{2}$ pydc, $0.085 \mathrm{~g}$ of $\mathrm{H}_{4} \mathrm{mpbp}, 0.255 \mathrm{~g}$ of $\mathrm{PrCl}_{3} \cdot 6 \mathrm{H}_{2} \mathrm{O}$ and $0.090 \mathrm{~g}$ of $\mathrm{NaOH}$ in $c a .11 \mathrm{~g}$ of distilled water was stirred through roughly to homogeneity for about $30 \mathrm{~min}$. The suspension, with a molar ratio of 1.0:1.0:2.0:6.3:1710, respectively, was transferred into a stainless steel reaction vessel $(\mathrm{ca} .40 \mathrm{~mL}$ of internal volume) which was placed inside a preheated oven at $180{ }^{\circ} \mathrm{C}$ for 3 days. Large single crystals of compound $\mathbf{3}$ were readily separated from a powdered impurity by sonication $(0.04 \mathrm{~g}$, yield of $c a$. $33 \%$ based on $\mathrm{H}_{2}$ pydc).

Selected FT-IR (KBr Pellets) and FT-Raman Main Bands (Inside the Parenthesis in Italics) (in $\left.\mathrm{cm}^{-1}\right) .3436$ b, $3120 \mathrm{w}(3121 \mathrm{w}, 3082 \mathrm{w}$, $3070 w), 1614 \mathrm{~s}, 1588 \mathrm{~s}(1597 \mathrm{~s}, 1557 w), 1481 \mathrm{w}(1485 w), 1410 \mathrm{~s}$ $(1437 s), 1358 \mathrm{~m}, 1277 \mathrm{w}(1283 w, 1261 w), 1177 \mathrm{w}(1185 w, 1158 w$, $1118 w), 1031 \mathrm{~m}, 950 \mathrm{w}, 884 \mathrm{w}(877 \mathrm{~m}), 834 \mathrm{~m}, 823 \mathrm{~m},(822 w)$, $761 \mathrm{~m}, 688 \mathrm{~m}, 644 \mathrm{w}(653 \mathrm{w}), 578 \mathrm{w}(582 \mathrm{w}), 539 \mathrm{~m}, 521 \mathrm{~m}$.

Thermogravimetric Analysis (TGA) Data (Weight Losses in \%). $31-274{ }^{\circ} \mathrm{C}+3.7 \%, 274-450{ }^{\circ} \mathrm{C}-1.0 \%, 450-600{ }^{\circ} \mathrm{C}-41.9 \%$, $600-700{ }^{\circ} \mathrm{C}-0.9 \%$.
Single-Crystal X-ray Diffraction. Single-crystals of $\left(\mathrm{CH}_{3}\right)_{2} \mathrm{NH}_{2}[\mathrm{Ln}-$ (pydc) $\left.)_{2}\right] \cdot 1 / 2 \mathrm{H}_{2} \mathrm{O}$ [where $\mathrm{Ln}^{3+}$ is $\mathrm{Eu}^{3+}(\mathbf{1 a})$ or $\left.^{2} \mathrm{Er}^{3+}(\mathbf{1 b})\right],\left[\mathrm{Er}_{4}(\mathrm{OH})_{4^{-}}\right.$ (pydc) $\left.)_{4}\left(\mathrm{H}_{2} \mathrm{O}\right)_{3}\right] \cdot \mathrm{H}_{2} \mathrm{O}(2)$ and $\left[\mathrm{Pr}_{2}{ }_{2} \mathrm{Pr}^{\mathrm{IV}}{ }_{1.25} \mathrm{O}(\mathrm{OH})_{3}(\text { pydc })_{3}\right]$ (3) (where pydc $^{2-}=2,5$-pyridinedicarboxylate) were manually harvested from the crystallization vials and mounted on Hampton Research CryoLoops using FOMBLIN Y perfluoropolyether vacuum oil (LVAC 25/6) purchased from Aldrich ${ }^{18}$ with the help of a Stemi 2000 stereomicroscope equipped with Carl Zeiss lenses. Data were collected on a Bruker X8 Kappa APEX II charge-coupled device (CCD) area-detector diffractometer (Mo K $\alpha$ graphite-monochromated radiation, $\lambda=0.71073$ $\AA$ ) controlled by the APEX-2 software package, ${ }^{19}$ and equipped with an Oxford Cryosystems Series 700 cryostream monitored remotely using the software interface Cryopad. ${ }^{20}$ Images were processed using the software package SAINT,$+{ }^{21}$ and data were corrected for absorption by the multiscan semiempirical method implemented in SADABS. ${ }^{22}$ Structures were solved using the Patterson synthesis algorithm implemented in SHELXS-97, ${ }^{23}$ which allowed the immediate location of the crystallographically independent $\mathrm{Ln}^{3+}$ metallic centers. All remaining non-hydrogen atoms were directly located from difference Fourier maps calculated from successive full-matrix least-squares refinement cycles on $F^{2}$ using SHELXL-97. ${ }^{24}$ Non-hydrogen atoms were successfully refined using anisotropic displacement parameters.

The crystal structures of compounds $\mathbf{1 a}$ and $\mathbf{1 b}$ contain eight solventaccessible voids as revealed by PLATON (each accounting for $c a .182$ and $\left.169 \AA^{3}\right),{ }^{25}$ which were found to be partially occupied by highly disordered water molecules of crystallization. One oxygen atom (refined assuming an isotropic displacement behavior) belonging to these chemical entities was directly located from difference Fourier maps, and its site occupancy was fixed at $50 \%$ (value obtained from unrestrained refinement cycles) during the last stages of the overall structural refinement. Even though the hydrogen atoms associated with these water molecules were not visible from difference Fourier maps, they have been added to the empirical formulae of the compounds (Table 1). It is important to emphasize that this partially occupied water molecule does account for all electron density in the structures. Indeed, 1a and 1b still have approximately 17.0 and 16.3\% (ca. 1454 and 1348 $\AA^{3}$, respectively) of solvent-accessible volume with 664 and 360 electrons per unit cell, respectively, as revealed by PLATON. The inclusion of additional water molecules in the empty spaces did not proceed with sensible structural refinements. The discrepancy in the number of electrons between $\mathbf{1 a}$ and $\mathbf{1 b}$ also suggests that these values are highly random and dependent on the crystal selected for data collection. Compound $\mathbf{2}$ contains three empty cavities in the unit cell accounting for $c a .286 \AA^{3}$ of solvent accessible volume ( $c a .14 .2 \%$ of the volume of the unit cell) and containing $c a$. 132 electrons. As for the two previous structures, the inclusion of additional water molecules in the voids was revealed unsuccessful. Structural refinements using solvent-free reflection data calculated using PLATON for the three structures did not produce substantial increments in the overall quality of the structures ( $R$-factors remained almost unaffected). Hence, the structural models using the original data sets were selected.

In compound 3 the Pr2 metallic center was found to be present in only half of the unit cells as undoubtedly revealed by unrestrained refinement of the site occupancy. The structure described in this paper has fixed site occupancy of 50\% for Pr2 which leads to a deficiency of positive charge in the material. It is important to stress that single crystal data were intentionally collected up to $45.28^{\circ}$ ( $0.5 \AA$ resolution; data completeness of $99.5 \%$ ) in order to investigate the eventual presence of protonating hydrogen atoms on the coordinated pydc $^{2-}$ ligands. It is widely known that praseodymium can adopt variable valences $(+3$ or +4$)$ while forming oxides, with the extreme cases being $\operatorname{Pr}_{2} \mathrm{O}_{3}(+3$ - hexagonal or cubic structure $)^{26,27}$ and $\mathrm{PrO}_{2}\left(+4\right.$ - cubic structure) ${ }^{27}$ It is thus feasible to assume that the praseodymium centers appear in the crystal structure of $\mathbf{3}$ having the two previously mentioned oxidation states, with an average charge per center of about +3.38 agreeing well with the intermediate known $\mathrm{PrO}_{1.67}$ phase. ${ }^{27}$ Hence the empirical formula of $\left[\mathrm{Pr}^{\mathrm{III}}{ }_{2} \mathrm{Pr}^{\mathrm{IV}}{ }_{1.25} \mathrm{O}(\mathrm{OH})_{3}(\text { pydc })_{3}\right]$ for this compound. Moreover, this +3.38 value is not unrealistic because the widely known $\operatorname{Pr}_{6} \mathrm{O}_{11}$ phase (stable at ambient temperature and in open air) is an oxygendeficient modification of $\mathrm{PrO}_{2}$ with an average charge of +3.67 per metallic center.

In $\mathbf{2}$ and $\mathbf{3}$ the hydrogen atoms associated with the $\mu_{3}$-bridging hydroxyl groups were markedly visible in difference Fourier maps and were included in the final structural models with the $\mathrm{O}-\mathrm{H}$ distances restrained to $0.95(1) \AA$ and $U_{\text {iso }}$ fixed at $1.5 \times U_{\text {eq }}$ of the attached oxygen 
Table 1. Crystal Data Collection and Refinement Details for $\left(\mathrm{CH}_{3}\right)_{2} \mathrm{NH}_{2}\left[\mathrm{Ln}(\mathrm{pydc})_{2}\right] \cdot 1 / 2 \mathrm{H}_{2} \mathrm{O}$ [where $\mathrm{Ln}^{3+}$ is $\mathrm{Eu}^{3+}(1 \mathrm{a})$ or $\left.\mathrm{Er}^{3+}(1 \mathrm{~b})\right]$, $\left[\mathrm{Er}_{4}(\mathrm{OH})_{4}(\mathrm{pydc})_{4}\left(\mathrm{H}_{2} \mathrm{O}\right)_{3}\right] \cdot \mathrm{H}_{2} \mathrm{O}(2)$ and $\left[\mathrm{Pr}^{\mathrm{III}}{ }_{2} \mathrm{Pr}^{\mathrm{IV}}{ }_{1.25} \mathrm{O}(\mathrm{OH})_{3}(\mathrm{pydc})_{3}\right](3)$

\begin{tabular}{|c|c|c|c|c|}
\hline & $\mathbf{1 a}\left(\mathrm{Eu}^{3+}\right)$ & $\mathbf{1 b}\left(\mathrm{Er}^{3+}\right)$ & 2 & 3 \\
\hline formula & $\mathrm{C}_{64} \mathrm{H}_{60} \mathrm{Eu}_{4} \mathrm{~N}_{12} \mathrm{O}_{34}$ & $\mathrm{C}_{64} \mathrm{H}_{60} \mathrm{Er}_{4} \mathrm{~N}_{12} \mathrm{O}_{34}$ & $\mathrm{C}_{28} \mathrm{H}_{24} \mathrm{Er}_{4} \mathrm{~N}_{4} \mathrm{O}_{24}$ & $\mathrm{C}_{21} \mathrm{H}_{12} \mathrm{~N}_{3} \mathrm{O}_{16} \mathrm{Pr}_{3.25}$ \\
\hline formula weight & 2149.08 & 2210.28 & 1469.55 & 1020.29 \\
\hline temperature/K & $150(2)$ & $100(2)$ & $157(2)$ & $150(2)$ \\
\hline crystal type & colorless needles & pink prism & pink plates & blue prisms \\
\hline crystal size $/ \mathrm{mm}$ & $0.12 \times 0.04 \times 0.04$ & $0.20 \times 0.18 \times 0.10$ & $0.09 \times 0.06 \times 0.02$ & $0.20 \times 0.20 \times 0.10$ \\
\hline crystal system & orthorhombic & orthorhombic & triclinic & hexagonal \\
\hline space group & $F d d d$ & $F d d d$ & $P \overline{1}$ & $R \overline{3}$ \\
\hline$a / \AA$ & $26.7127(8)$ & $26.4473(16)$ & $8.7088(4)$ & $22.6389(6)$ \\
\hline$b / \AA ̊$ & $17.9748(7)$ & $17.9442(10)$ & $14.9170(8)$ & $22.6389(6)$ \\
\hline$c / \AA$ & $17.8024(7)$ & $17.3804(11)$ & $15.9485(7)$ & $9.3466(5)$ \\
\hline$\alpha /{ }^{\circ}$ & 90 & 90 & $86.067(2)$ & 90 \\
\hline$\beta /^{\circ}$ & 90 & 90 & $79.917(2)$ & 90 \\
\hline$\gamma /{ }^{\circ}$ & 90 & 90 & $81.642(3)$ & 120 \\
\hline volume $/ \AA^{3}$ & $8547.9(5)$ & $8248.3(9)$ & 2016.21(17) & $4148.5(3)$ \\
\hline Z & 4 & 4 & 2 & 6 \\
\hline$\rho_{\text {calculated }} / \mathrm{g} \mathrm{cm}^{-3}$ & 1.670 & 1.780 & 2.421 & 2.450 \\
\hline$\mu / \mathrm{mm}^{-1}$ & 2.981 & 4.118 & 8.332 & 5.713 \\
\hline$\theta$ range $^{\circ}$ & $3.56-25.32$ & $3.61-25.35$ & $3.68-30.51$ & $3.60-45.28$ \\
\hline \multirow[t]{3}{*}{ index ranges } & $-26 \leq h \leq 27$ & $-31 \leq h \leq 27$ & $-12 \leq h \leq 12$ & $-45 \leq h \leq 40$ \\
\hline & $-21 \leq k \leq 14$ & $-17 \leq k \leq 21$ & $-21 \leq k \leq 21$ & $-45 \leq k \leq 45$ \\
\hline & $-20 \leq l \leq 21$ & $-20 \leq l \leq 19$ & $-22 \leq l \leq 22$ & $-18 \leq l \leq 18$ \\
\hline collected reflections & 8231 & 20998 & 144302 & 77472 \\
\hline \multirow[t]{2}{*}{ independent reflections } & 1840 & 1883 & 12158 & 7687 \\
\hline & $\left(R_{\text {int }}=0.0357\right)$ & $\left(R_{\mathrm{int}}=0.0320\right)$ & $\left(R_{\mathrm{int}}=0.0452\right)$ & $\left(R_{\mathrm{int}}=0.0294\right)$ \\
\hline \multirow[t]{2}{*}{ final $R$ indices $[I>2 \sigma(I)]^{a, b}$} & $R 1=0.0267$ & $R 1=0.0235$ & $R 1=0.0255$ & $R 1=0.0203$ \\
\hline & $\mathrm{w} R 2=0.0746$ & $\mathrm{w} R 2=0.0629$ & $\mathrm{w} R 2=0.0559$ & $\mathrm{w} R 2=0.0500$ \\
\hline \multirow[t]{2}{*}{ final $R$ indices (all data) $)^{a, b}$} & $R 1=0.0370$ & $R 1=0.0275$ & $R 1=0.0351$ & $R 1=0.0325$ \\
\hline & $\mathrm{w} R 2=0.0799$ & $\mathrm{w} R 2=0.0648$ & $\mathrm{w} R 2=0.0600$ & $\mathrm{w} R 2=0.0508$ \\
\hline largest diff peak and hole/e $\AA^{-3}$ & 0.717 and -0.665 & 0.871 and -0.842 & 1.773 and -1.669 & 2.364 and -1.777 \\
\hline CCDC no. & 685773 & 685774 & 685775 & 685776 \\
\hline
\end{tabular}

${ }^{a} R 1=\Sigma|| F_{\mathrm{o}}|-| F_{\mathrm{c}}\left|/ \sum\right| F_{\mathrm{o}} \mid{ }^{b} w R 2=\sqrt{ } \sum\left[w\left(F_{\mathrm{o}}^{2}-F_{\mathrm{c}}^{2}\right)^{2}\right] / \Sigma\left[w\left(F_{\mathrm{o}}^{2}\right)^{2}\right]$.

atom. The hydrogen atoms belonging to the water molecules present in structure 2 (both coordinated - O1W to O3W - and located in the voids - O4W) were also found in difference Fourier maps and placed in the structural model with the $\mathrm{O}-\mathrm{H}$ and $\mathrm{H} \cdots \mathrm{H}$ distances restrained to $0.95(1)$ and $1.55(1) \AA$, plus $U_{\text {iso }}(\mathrm{H})=1.5 \times U_{\text {eq }}(\mathrm{O})$, in order to ensure a chemically reasonable geometry for these chemical entities. Hydrogen atoms bound to carbon were located at their idealized positions in all structures using appropriate HFIX instructions in SHELXL (43 for the aromatic, 23 for the $-\mathrm{NH}_{2}$ moieties and 137 for the terminal methyl groups) and included in subsequent refinement cycles in riding-motion approximation with isotropic thermal displacements parameters $\left(U_{\text {iso }}\right)$ fixed at 1.2 (for the former family of hydrogen atoms) or 1.5 (for the $-\mathrm{NH}_{2}$ and methyl moieties) times $U_{\mathrm{eq}}$ of the carbon atom to which they are attached.

The last difference Fourier map synthesis showed: for 1a, the highest

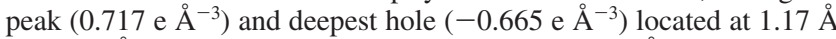
and $1.19 \AA$ from $\mathrm{O} 4$; for $\mathbf{1 b}$, the highest peak $\left(0.871 \mathrm{e} \AA^{-3}\right)$ and deepest

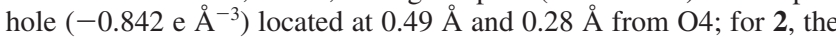
highest peak $\left(1.773 \mathrm{e} \AA^{-3}\right)$ and deepest hole $\left(-1.669 \mathrm{e} \AA^{-3}\right)$ located at $0.79 \AA$ and $0.76 \AA$ from $\operatorname{Er}(3)$; for 3 , the highest peak $\left(2.364 \mathrm{e}^{-3}\right)$

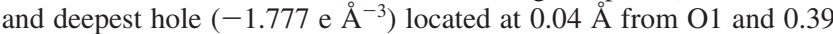
$\AA$ from $\operatorname{Pr}(1)$

Crystallographic data (excluding structure factors) for the structures reported in this paper have been deposited with the Cambridge Crystallographic Data Centre as supplementary publication data (deposition numbers are given in Table 1). Copies of the data can be obtained free of charge on application to CCDC, 12 Union Road, Cambridge CB2 2EZ, U.K. FAX: (+44) 1223 336033. E-mail: deposit@ccdc.cam.ac.uk.

\section{Results and Discussion}

Crystal Structure Description. A series of crystalline threedimensional (3D) LnOFs were isolated using solvothermal (1a and $\mathbf{1 b}$ ) and hydrothermal ( $\mathbf{2}$ and $\mathbf{3}$ ) synthetic approaches (see Experimental Section for details) and formulated as $\left(\mathrm{CH}_{3}\right)_{2} \mathrm{NH}_{2-}$ [ $\left.\mathrm{Ln}(\text { pydc })_{2}\right] \cdot 1 / 2 \mathrm{H}_{2} \mathrm{O}$ [where $\left(\mathrm{CH}_{3}\right)_{2} \mathrm{NH}_{2}{ }^{+}$is the dimethylamonium cation; $\mathrm{Ln}^{3+}=\mathrm{Eu}^{3+}$ (1a) or $\mathrm{Er}^{3+}(\mathbf{1 b})$; pydc $^{2-}$ is the dianionic residue of 2,5-pyridinedicarboxylic acid $\left(\mathrm{H}_{2}\right.$ pydc)], $\left[\mathrm{Er}_{4}(\mathrm{OH})_{4}(\mathrm{pydc})_{4}\left(\mathrm{H}_{2} \mathrm{O}\right)_{3}\right] \cdot \mathrm{H}_{2} \mathrm{O}$ (2), and $\left[\mathrm{Pr}^{\mathrm{III}}{ }_{2} \mathrm{Pr}^{\mathrm{IV}}{ }_{1.25} \mathrm{O}(\mathrm{OH})_{3^{-}}\right.$ $(\text { pydc) })_{3}$ ] (3) on the basis of single-crystal diffraction studies (Table 1) in combination with thermoanalytical investigations, vibrational (FT-IR and FT-Raman) spectroscopy studies and elemental composition analysis. Energy dispersive analysis of $\mathrm{X}$-ray spectroscopy (EDS) investigations (data not shown) on single crystals of all compounds provided qualitative confirmation about the presence of the lanthanides. CHN elemental composition agrees well with the empirical formulae derived from single-crystal X-ray diffraction (XRD) data. Scanning electron microscopy (SEM) images and powder XRD patterns (data not shown) of the bulk samples suggest the presence of homogeneous pure phases.

All LnOF materials are 3D connected modular frameworks based on distinct lanthanide clusters building units: dimers in compounds $\mathbf{1 a}$ and $\mathbf{1 b}$, a tetramer in $\mathbf{2}$, and a hexamer in $\mathbf{3}$ (see structural details in the following paragraphs). Clustering of lanthanide centers (observed in the two latter compounds) seems to occur preferentially when water is employed as the solvent media (hydrothermal approach) instead of DMF (solvothermal synthesis). Moreover, from the chemical composition of the initial reactive mixtures (see Experimental section for details), it is feasible to infer that large clusters are preferentially obtained for more diluted gels having a metal/ $\mathrm{H}_{2}$ pydc ratio greater than unity. Family $\mathbf{1}$ of materials contains in the void spaces of the anionic frameworks $\left(\mathrm{CH}_{3}\right)_{2} \mathrm{NH}_{2}{ }^{+}$cations (based on crystallographic and vibrational spectroscopy evidence). These chemical species are most likely generated in situ by the solvolysis of DMF. Indeed, this type of decomposition of DMF is not unprecedented, and it is even known to direct the formation of peculiar anionic frameworks through a typical templating effect. ${ }^{28}$ 


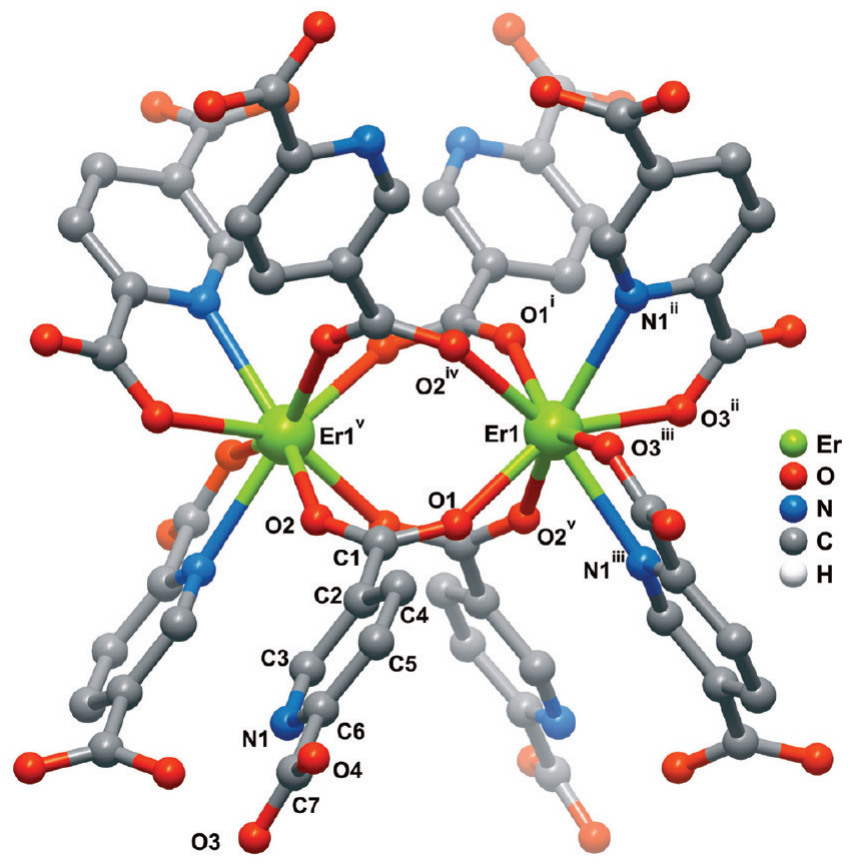

Figure 1. Ball-and-stick representation of the Er dimeric cluster in $\left(\mathrm{CH}_{3}\right)_{2} \mathrm{NH}_{2}\left[\mathrm{Er}(\text { pydc })_{2}\right] \cdot 1 / 2 \mathrm{H}_{2} \mathrm{O}(\mathbf{1 b})$, showing the labeling scheme for all atoms belonging to the assymmetric unit and the Er1 coordination environment. Hydrogen atoms were ommited for clarity. For selected bond lengths and angles see Tables 2 and 3. Symmetry transformations used to generate equivalent atoms: (i) $-x-1 / 4,-y+3 / 4, z$; (ii) $x-$ $1 / 4,-y+1 / 2, z+1 / 4$; (iii) $-x, y+1 / 4, z+1 / 4$; (iv) $-x-1 / 4, y,-z$ $+3 / 4$; (v) $x,-y+3 / 4,-z+3 / 4$.

Frameworks Based on Dimeric $\mathbf{L n}^{3+}$ Clusters. 3D LnOFs formulated as $\left(\mathrm{CH}_{3}\right)_{2} \mathrm{NH}_{2}\left[\mathrm{Eu}(\text { pydc })_{2}\right] \cdot 1 / 2 \mathrm{H}_{2} \mathrm{O}(\mathbf{1 a})$ and $\left(\mathrm{CH}_{3}\right)_{2^{-}}$ $\mathrm{NH}_{2}\left[\mathrm{Er}(\text { pydc })_{2}\right] \cdot 1 / 2 \mathrm{H}_{2} \mathrm{O}$ (1b) were obtained by solvothermal synthetic approaches and found to be isostructural, crystallizing in the orthorhombic $F d d d$ space group (Table 1). Even though the crystal structures have been fully determined and refined for the two compounds, the described crystallographic details will be focused on the Er-based material, being also valid for 1a unless otherwise stated.

Compound 1b contains a single crystallographically independent lanthanide center $\left(\mathrm{Er}^{3+}\right)$ which is coordinated to six $\mathrm{O}-$ and two $\mathrm{N}$-atoms from six symmetry-related pydc ${ }^{2-}$ ligands describing an eight-coordination sphere (Figure 1), $\left\{\mathrm{ErN}_{2} \mathrm{O}_{6}\right\}$, which resembles a distorted square antiprism (Figure 2): on the one hand, while the $\mathrm{Er}-\mathrm{O}$ bond distances range from 2.276(3) to $2.348(3) \AA$ the single $\mathrm{Er}-\mathrm{N}$ bond length is considerably longer, 2.518(3) $\AA$ (Table 2); on the other, the range of internal $(\mathrm{N}, \mathrm{O})-\mathrm{Er}-(\mathrm{N}, \mathrm{O})$ angles for each base of the square antiprism are markedly distinct, ranging from $65.83(10)^{\circ}$ to $71.78(11)^{\circ}$ for the $\mathrm{N} 1^{\mathrm{ii}} \rightarrow \mathrm{O}^{\mathrm{ii}} \rightarrow \mathrm{N} 1^{\mathrm{iii}} \rightarrow \mathrm{O}^{\mathrm{iii}}$ base, and from $74.76(12)^{\circ}$ to $77.88(13)^{\circ}$ for the $\mathrm{O} 1 \rightarrow \mathrm{O} 2^{\mathrm{iv}} \rightarrow \mathrm{O}^{1 \mathrm{i}} \rightarrow \mathrm{O} 2^{\mathrm{v}}$ base (Figure 1 and Table 3).

The crystallographically independent anionic pydc ${ }^{2-}$ ligand is connected to three symmetry-related $\mathrm{Er}^{3+}$ optical centers via two different coordination fashions, ultimately appearing in the structure as a tridentate ligand (Scheme 1a). The heteroatom of the aromatic ring forms with the adjacent carboxylate group a typical $\mathrm{N}, \mathrm{O}$-chelate (mode II), with the observed bite angle being of $65.83(10)^{\circ}$. The carboxylate group connects two neighboring $\mathrm{Er}^{3+}$ centers via a $\mu_{2}-\mathrm{syn}$,syn-bridge (mode I), being ultimately responsible for the formation of a centrosymmetric dimeric unit. This block can also be envisaged a secondary building unit (SBU) in the construction of the 3D framework (see below):

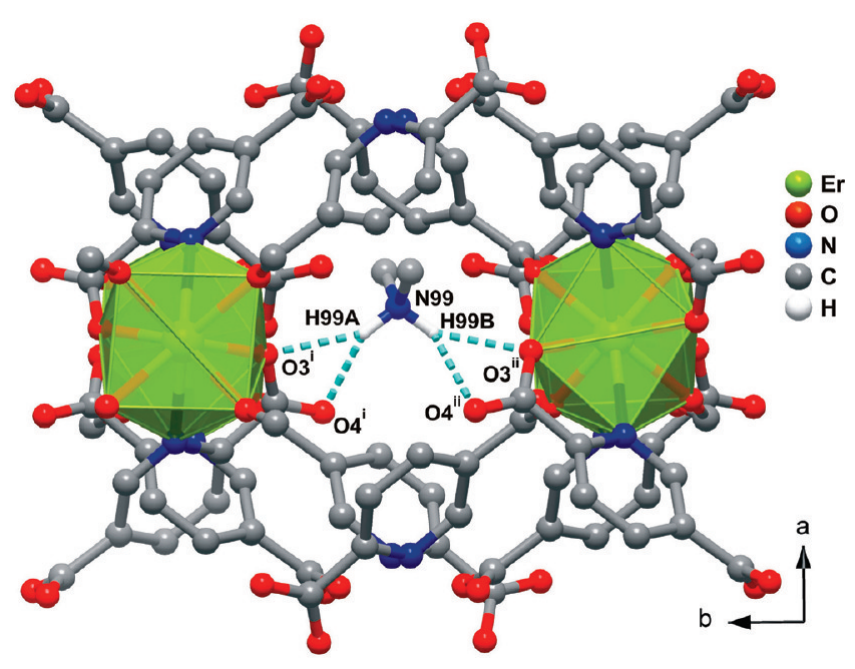

Figure 2. Hydrogen bonding interactions between the dimethylamonium cations, $\left(\mathrm{CH}_{3}\right)_{2} \mathrm{NH}_{2}^{+}$, and the anionic 3D framework in $\left(\mathrm{CH}_{3}\right)_{2} \mathrm{NH}_{2^{-}}$ $\left[\mathrm{Er}(\text { pydc })_{2}\right](\mathbf{1 b})$, showing the labeling scheme for all the atoms directly involved in these interactions. Hydrogen atoms bonded to carbon have been omitted for clarity. Symmetry transformations used to generate equivalent atoms: (i) $-x-1 / 4,-y+3 / 4, z$; (ii) $x-1 / 4,-y+1 / 2$, $z+1 / 4$.

Table 2. Selected Bond Lengths (in $\AA$ ) for the $\left\{\operatorname{LnN}_{2} \mathrm{O}_{6}\right\}$ Coordination Environments Present in $\left(\mathrm{CH}_{3}\right)_{2} \mathrm{NH}_{2}\left[\mathrm{Ln}(\text { pydc })_{2}\right] \cdot$ $1 / 2 \mathrm{H}_{2} \mathrm{O},\left[\mathrm{Ln}^{3+} \text { is } \mathrm{Eu}^{3+}(1 \mathrm{a}) \text { or } \mathrm{Er}^{3+}(1 \mathrm{~b})\right]^{a}$

\begin{tabular}{lcc}
\hline & $\mathbf{1 a}\left(\mathrm{Eu}^{3+}\right)$ & $\mathbf{1 b}\left(\mathrm{Er}^{3+}\right)$ \\
\hline Ln1-O1 & $2.324(4)$ & $2.276(3)$ \\
Ln1-O1 & $2.324(4)$ & $2.276(3)$ \\
Ln1-O(3)ii & $2.375(3)$ & $2.310(3)$ \\
Ln1-O3 & $2.375(3)$ & $2.310(3)$ \\
Ln1-O2 & $2.416(3)$ & $2.348(3)$ \\
Ln1-O2 & $2.416(3)$ & $2.348(3)$ \\
Ln1- $1^{\text {ii }}$ & $2.580(4)$ & $2.518(3)$ \\
Ln1-N1 & $2.580(4)$ & $2.518(3)$
\end{tabular}

${ }^{a}$ Symmetry transformations used to generate equivalent atoms: (i) $-x$ $-1 / 4,-y+3 / 4, z$; (ii) $x-1 / 4,-y+1 / 2, z+1 / 4$; (iii) $-x, y+1 / 4, z$ $+1 / 4$; (iv) $-x-1 / 4, y,-z+3 / 4$; (v) $x,-y+3 / 4,-z+3 / 4$.

Table 3. Selected Angles (in degrees) for the $\left\{\operatorname{LnN}_{2} \mathrm{O}_{6}\right\}$ Coordination Environments Present in $\left(\mathrm{CH}_{3}\right)_{2} \mathrm{NH}_{2}\left[\mathrm{Ln}(\text { pydc })_{2}\right] \cdot 1 / 2 \mathrm{H}_{2} \mathrm{O},\left[\mathrm{Ln}^{3+}\right.$ is $\mathrm{Eu}^{3+}(1 \mathrm{a}){\mathrm{or} \mathrm{Er}^{3+}}^{(1 \mathrm{~b})]^{a}}$

\begin{tabular}{|c|c|c|}
\hline & 1a $\left(\mathrm{Eu}^{3+}\right)$ & 1b $\left(\mathrm{Er}^{3+}\right)$ \\
\hline $\mathrm{O} 1-\mathrm{Ln} 1-\mathrm{O} 1^{\mathrm{i}}$ & $116.3(2)$ & 117.91(17) \\
\hline $\mathrm{O} 1-\mathrm{Ln} 1-\mathrm{O} 3^{\mathrm{ii}}$ & $151.16(13)$ & $147.76(11)$ \\
\hline $\mathrm{O} 1-\mathrm{Ln} 1-\mathrm{O} 3^{\mathrm{iii}}$ & $80.15(14)$ & $80.00(12)$ \\
\hline $\mathrm{O} 1-\mathrm{Ln} 1-\mathrm{O} 2^{\mathrm{iv}}$ & 73.99(14) & $74.76(12)$ \\
\hline $\mathrm{O} 1-\mathrm{Ln} 1-\mathrm{O} 2^{\mathrm{v}}$ & $78.18(15)$ & $77.88(13)$ \\
\hline $\mathrm{O} 1-\mathrm{Ln} 1-\mathrm{N} 1^{\mathrm{ii}}$ & $138.35(14)$ & $140.32(12)$ \\
\hline $\mathrm{O} 1-\mathrm{Ln} 1-\mathrm{N} 1^{\mathrm{iii}}$ & $80.99(13)$ & $78.56(11)$ \\
\hline $\mathrm{O} 1^{\mathrm{i}}-\mathrm{Ln} 1-\mathrm{O} 3^{\mathrm{ii}}$ & $80.15(14)$ & $80.00(12)$ \\
\hline $\mathrm{O} 3^{\mathrm{ii}}-\mathrm{Ln} 1-\mathrm{O} 3^{\mathrm{iii}}$ & $96.20(18)$ & $98.66(16)$ \\
\hline $\mathrm{O} 3^{\mathrm{ii}}-\mathrm{Ln} 1-\mathrm{O}^{2 \mathrm{iv}}$ & $134.50(12)$ & $137.30(11)$ \\
\hline $\mathrm{O} 3^{\mathrm{ii}}-\mathrm{Ln} 1-\mathrm{O} 2^{\mathrm{v}}$ & $84.69(13)$ & $82.10(11)$ \\
\hline $\mathrm{O} 3^{\mathrm{ii}}-\mathrm{Ln} 1-\mathrm{N} 1^{\mathrm{ii}}$ & $64.12(13)$ & $65.83(10)$ \\
\hline $\mathrm{O} 3^{\mathrm{ii}}-\mathrm{Ln} 1-\mathrm{N} 1^{\mathrm{iii}}$ & $71.89(12)$ & $71.78(11)$ \\
\hline $\mathrm{O} 2^{\mathrm{iv}}-\mathrm{Ln} 1-\mathrm{O} 2^{\mathrm{v}}$ & $125.81(18)$ & $125.44(15)$ \\
\hline $\mathrm{O} 2^{\mathrm{iv}}-\mathrm{Ln} 1-\mathrm{N} 1^{\mathrm{ii}}$ & $73.26(12)$ & 74.23(11) \\
\hline $\mathrm{O} 2^{\mathrm{iv}}-\mathrm{Ln} 1-\mathrm{N} 1^{\mathrm{iii}}$ & $142.92(14)$ & $141.24(12)$ \\
\hline $\mathrm{N} 1^{\mathrm{ii}}-\mathrm{Ln} 1-\mathrm{N} 1^{\mathrm{iii}}$ & $111.95(17)$ & $112.72(15)$ \\
\hline
\end{tabular}

${ }^{a}$ Symmetry transformations used to generate equivalent atoms: (i) $-x$ $-1 / 4,-y+3 / 4, z$; (ii) $x-1 / 4,-y+1 / 2, z+1 / 4$; (iii) $-x, y+1 / 4, z$ $+1 / 4$; (iv) $-x-1 / 4, y,-z+3 / 4$; (v) $x,-y+3 / 4,-z+3 / 4$.

four carboxylate groups belonging to four symmetry related pydc ${ }^{2-}$ ligands connect a pair of $\mathrm{Er}^{3+}$ atoms generating a typical dimeric paddle-wheel-like centrosymmetric motif, $\left\{\mathrm{Er}_{2}\left(\mathrm{CO}_{2}\right)_{4}\right\}$, 
Scheme 1. Coordination Modes of the pyde ${ }^{2-}$ Anionic Ligand Which Appear in the Three Types of 3D LnOF Materials<smiles></smiles>

(a)

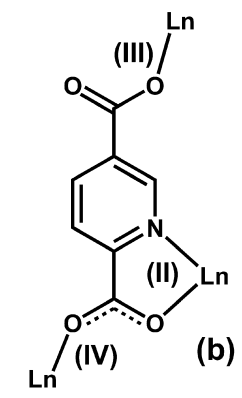<smiles></smiles>

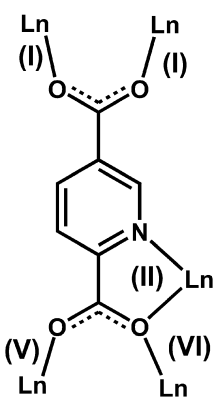

(d) with the intradimer $\operatorname{Er} 1 \cdots \operatorname{Er}^{\mathrm{v}}{ }^{\mathrm{v}}$ distance being 4.4435(4) $\AA$ (Figure 1) [symmetry code: (v) $x,-y+3 / 4,-z+3 / 4$ ].

pydc $^{2-}$ Ligands interconnect adjacent optical centrosymmetric dimers into an anionic 3D framework, $\infty_{\infty}^{3}\left\{\left[\operatorname{Er}(\text { pydc })_{2}\right]^{-}\right\}$, which has a brick-wall-like distribution of the lanthanide dimeric clusters in the $a b$ plane (Figure 3a). Noteworthy, a search in the literature and in the Cambridge Structural Database (CSD, version 5.29, November 2007) ${ }^{29}$ reveals that despite several LnOFs incorporating $\mathrm{H}_{2-x}$ pydc ${ }^{x-}$ residues being known to date (30 entries in the CSD), compounds $\mathbf{1 a}$ and $\mathbf{1 b}$ are indeed unique: to the best of our knowledge these are the first examples of charged LnOFs with $\mathrm{H}_{2-x}$ pydc ${ }^{x-}$. This anionic 3D network contains a two-dimensional system of channels clearly visible along the [001] and [011] directions of the unit cell, which are templated by the dimethylamonium counter-ions, $\left(\mathrm{CH}_{3}\right)_{2} \mathrm{NH}_{2}{ }^{+}$ (Figure $3 \mathrm{a}$ and $3 \mathrm{~b}$, respectively). The structural position of these cations is directed by four strong and highly directional $\mathrm{N}-\mathrm{H} \cdots \mathrm{O}$ hydrogen bonds (two pairs of bifurcated interactions - light-blue dashed lines in Figure 2 and Figure S1, Supporting Information), involving the coordinated (O3) and uncoordinated (O4) oxygen atoms of the carboxylate group adjacent to the heteroatom in the aromatic ring: $\mathrm{N} 99-\mathrm{H} 99 \mathrm{~A} \cdots \mathrm{O} 3^{\mathrm{i}}$ with $d(\mathrm{D} \cdots \mathrm{A})=2.984(4) \AA$ and $\angle(\mathrm{DHA})=154(8)^{\circ}$; N99-H99A $\cdots$ O $4^{\mathrm{i}}$ with $d(\mathrm{D} \cdots \mathrm{A})=2.802(7) \AA$ and $<(\mathrm{DHA})$ $=136(3)^{\circ}$; N99-H99B $\cdots \mathrm{O}^{\mathrm{ii}}$ with $d(\mathrm{D} \cdots \mathrm{A})=2.984(4) \AA$ and $\angle(\mathrm{DHA})=154(8)^{\circ}$; N99-H99B $\cdots \mathrm{O}^{4 \mathrm{ii}}$ with $d(\mathrm{D} \cdots \mathrm{A})=$ $2.802(7) \AA$ and $\angle\left(\right.$ DHA) $=136(3)^{\circ}$ [symmetry codes: (i) $x, y$ $+1, z$ and (ii) $x,-y+3 / 4,-z+3 / 4]$.

Framework Based on a Tetrameric $\mathbf{L n}^{3+}$ Cluster. The modular material $\left[\mathrm{Er}_{4}(\mathrm{OH})_{4}(\text { pydc })_{4}\left(\mathrm{H}_{2} \mathrm{O}\right)_{3}\right] \cdot \mathrm{H}_{2} \mathrm{O}(2)$ is based instead on a tetranuclear cluster composed of four crystallographically independent $\mathrm{Er}^{3+}$ centers which are joined together by four $\mu_{3}$-bridging hydroxyl groups $(\mathrm{O} 1, \mathrm{O} 2, \mathrm{O} 3$, and $\mathrm{O} 4)$ leading to the formation of a cubane-like $\left[\mathrm{Er}_{4}\left(\mu_{3}-\mathrm{OH}\right)_{4}\right]^{8+}$ core (i.e., four $\mathrm{Er}^{3+}$ centers are bonded together by another four hydroxyl groups placed in opposite vertices of the cuboidal arrangement) surrounded by nine chelating and/or bridging pydc $^{2-}$ ligands (Figure 4 and Figure S2, Supporting Information). Despite several tetrameric cubane-type clusters of lan-
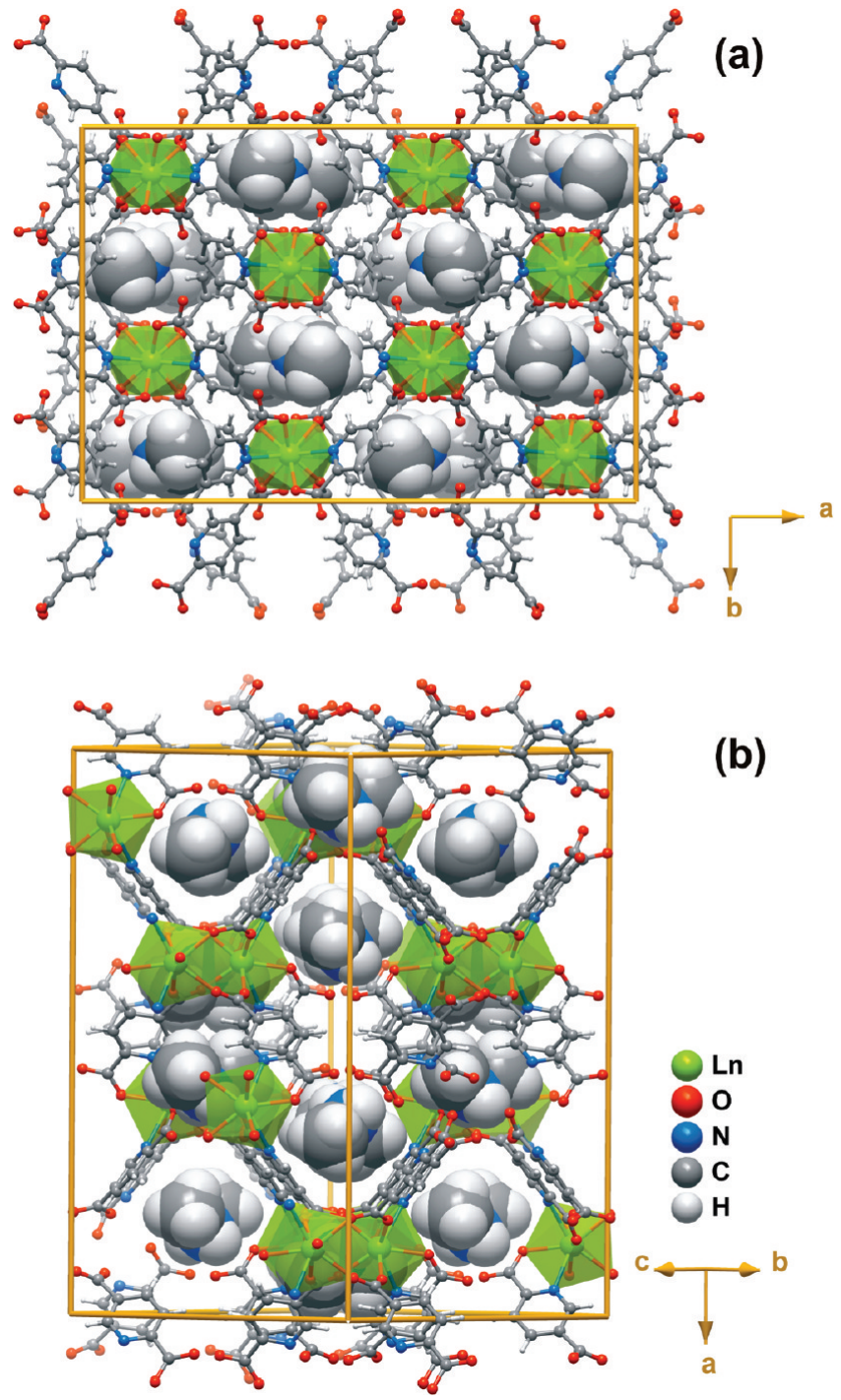

Figure 3. Schematic representation of the crystal packing of $\left(\mathrm{CH}_{3}\right)_{2} \mathrm{NH}_{2}-$ $\left[\mathrm{Er}(\text { pydc })_{2}\right] \cdot 1 / 2 \mathrm{H}_{2} \mathrm{O}(\mathbf{1 b})$ viewed in perspective along the (a) [001] and (b) [011] directions of the unit cell. The $\left(\mathrm{CH}_{3}\right)_{2} \mathrm{NH}_{2}{ }^{+}$cations housed within the channels of the anionic framework are represented in spacefilling mode and the $\mathrm{Er}^{3+}$ coordination environments as semitransparent polyhedra.

thanide centers and complexes incorporating $\mathrm{H}_{2-x}$ pydc ${ }^{x-}$ residues being known to date (as revealed by a systematic survey of the literature and the CSD), compound 2 represents, to the best of our knowledge, the first example of a framework-type material based on the modular assembly of this type of clusters having anionic $\mathrm{H}_{2-x}$ pydc ${ }^{x-}$ ligands as the organic bridges.

In the cubane-like tetranuclear cluster the four single $\mathrm{Er}^{3+}$ are located at the four apexes of a fairly regular tetrahedron [Er $\cdots$ Er distances ranging between 3.6718(3) and 3.8074(3) $\AA$ (average of $3.75 \AA$ ) - see Figure 5a for individual distances], with each of the triangular faces being capped by one of the four $\mu_{3}-\mathrm{OH}$ groups $[\mathrm{Er}-\mathrm{OH}$ distances ranging from 2.290(3) to 2.404(3) $\AA$ (average value of $2.35 \AA$ ) - Table 4]. This core is considerably distorted when compared to a perfect cube as clearly reflected by its internal angles: while the $\mathrm{HO}-\mathrm{Er}-\mathrm{OH}$ angles are found in the $102.5(1)-111.2(1)^{\circ}$ range (average $107.2^{\circ}$ ), the $\mathrm{Er}-\mathrm{OH}-\mathrm{Er}$ angles range instead from 68.09(9) to $71.73(9)^{\circ}$ (average $70.03^{\circ}$ ) (Tables 5 and 6). We note that these 


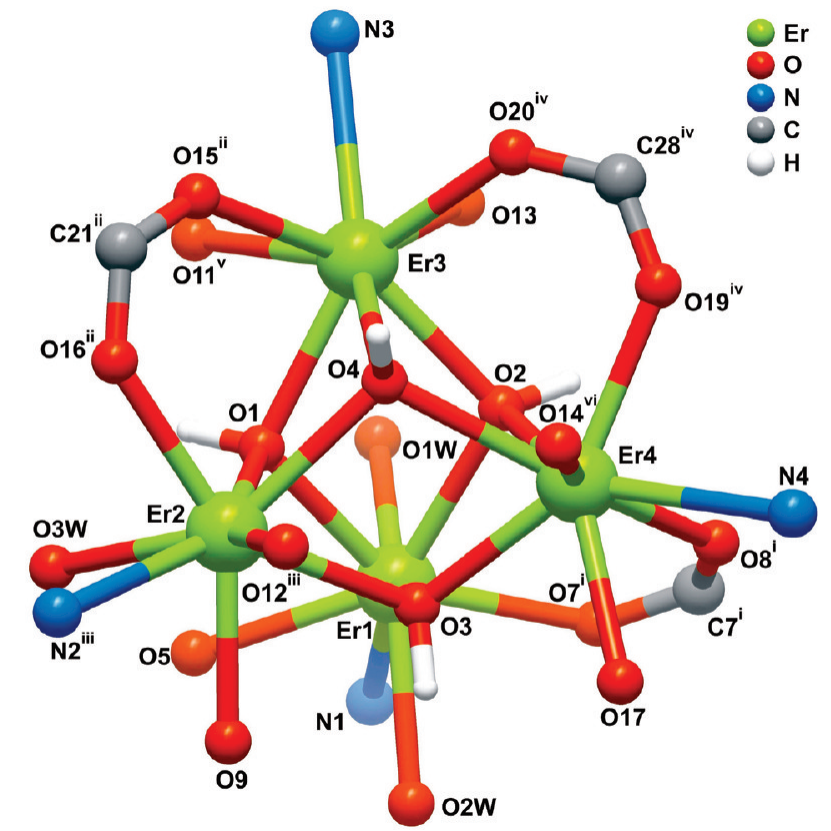

Figure 4. Ball-and-stick representation of the tetrameric cluster and the respective coordination environments for the four single $\mathrm{Er}^{3+}$ metallic centers in $\left[\mathrm{Er}_{4}(\mathrm{OH})_{4}(\text { pydc })_{4}\left(\mathrm{H}_{2} \mathrm{O}\right)_{3}\right] \cdot \mathrm{H}_{2} \mathrm{O}$ (2), showing the labeling scheme for all non-hydrogen atoms. For selected bond lengths and angles see Tables 4-6. Symmetry transformations used to generate equivalent atoms: (i) $-x+1,-y,-z+1$; (ii) $-x+1,-y+1,-z$; (iii) $-x,-y,-z$; (iv) $-x,-y+1,-z+1$; (v) $-x+1,-y,-z$; (vi) $x-1, y, z$.

Table 4. Selected Bond Lengths (in $\AA$ ) for the Four Distinct $\left\{\mathrm{ErNO}_{7}\right\}$ Coordination Environments Present in Compound $\left[\mathrm{Er}_{4}(\mathrm{OH})_{4}(\mathrm{pydc})_{4}\left(\mathrm{H}_{2} \mathrm{O}\right)_{3}\right] \cdot \mathrm{H}_{2} \mathrm{O}(2)^{a}$

\begin{tabular}{|c|c|c|c|}
\hline $\mathrm{Er} 1-\mathrm{O} 7^{\mathrm{i}}$ & $2.258(3)$ & $\mathrm{Er} 2-\mathrm{O} 9$ & $2.281(3)$ \\
\hline $\mathrm{Er} 1-\mathrm{O} 3$ & $2.304(2)$ & $\mathrm{Er} 2-\mathrm{O} 16^{\mathrm{ii}}$ & $2.297(3)$ \\
\hline $\mathrm{Er} 1-\mathrm{O} 1$ & $2.333(3)$ & $\mathrm{Er} 2-\mathrm{O} 12^{\mathrm{iii}}$ & $2.305(3)$ \\
\hline $\mathrm{Er} 1-\mathrm{O} 2 \mathrm{~W}$ & $2.346(3)$ & $\mathrm{Er} 2-\mathrm{O} 1$ & $2.314(2)$ \\
\hline Er1-O5 & $2.358(3)$ & $\mathrm{Er} 2-\mathrm{O} 3$ & $2.376(2)$ \\
\hline $\mathrm{Er} 1-\mathrm{O} 2$ & $2.404(3)$ & Er2-O4 & $2.382(3)$ \\
\hline $\mathrm{Er} 1-\mathrm{O} 1 \mathrm{~W}$ & $2.411(3)$ & $\mathrm{Er} 2-\mathrm{O} 3 \mathrm{~W}$ & $2.403(3)$ \\
\hline $\mathrm{Er} 1-\mathrm{N} 1$ & $2.485(3)$ & $\mathrm{Er} 2-\mathrm{N} 2^{\mathrm{iii}}$ & 2.581(3) \\
\hline $\mathrm{Er} 3-\mathrm{O} 2$ & $2.290(3)$ & Er4-O3 & $2.309(3)$ \\
\hline $\mathrm{Er} 3-\mathrm{O} 20^{\mathrm{iv}}$ & $2.305(3)$ & Er4-O14 $4^{\mathrm{vi}}$ & $2.315(3)$ \\
\hline $\mathrm{Er} 3-\mathrm{O} 1$ & $2.314(3)$ & Er4-O19iv & $2.318(3)$ \\
\hline $\mathrm{Er} 3-\mathrm{O} 15^{\mathrm{ii}}$ & $2.321(3)$ & Er4-O17 & $2.326(3)$ \\
\hline $\mathrm{Er} 3-\mathrm{O} 11^{\mathrm{v}}$ & $2.341(3)$ & $\mathrm{Er} 4-\mathrm{O}^{\mathrm{i}}$ & $2.363(3)$ \\
\hline $\mathrm{Er} 3-\mathrm{O} 13$ & $2.375(2)$ & $\mathrm{Er} 4-\mathrm{O} 2$ & $2.383(3)$ \\
\hline Er3-O4 & $2.395(2)$ & $\mathrm{Er} 4-\mathrm{O} 4$ & $2.388(3)$ \\
\hline $\mathrm{Er} 3-\mathrm{N} 3$ & $2.552(3)$ & Er4-N4 & 2.561(3) \\
\hline
\end{tabular}

${ }^{a}$ Symmetry transformations used to generate equivalent atoms: (i) $-x$ $+1,-y,-z+1$; (ii) $-x+1,-y+1,-z$; (iii) $-x,-y,-z$; (iv) $-x$, $-y+1,-z+1 ;(\mathrm{v})-x+1,-y,-z ;(\mathrm{vi}) x-1, y, z$.

structural features are comparable with those found in compounds comprising related distorted $\left[\mathrm{Er}_{4}\left(\mu_{3}-\mathrm{OH}\right)_{4}\right]^{8+}$ cluster cores. $^{30}$

This compound comprises four distinct anionic pydc ${ }^{2-}$ residues: while three ligands establish bridges between three adjacent $\mathrm{Er}^{3+}$ centers, showing the coordination fashions represented in Scheme 1a and $1 \mathrm{~b}$ (those containing the N1, N2, and N4 nitrogen atoms), one exhibits the coordination fashions depicted in Scheme 1c (that with N3). All Er ${ }^{3+}$ centers are eightcoordinated, $\left\{\mathrm{ErNO}_{7}\right\}$, with the coordination geometries resembling distorted dodecahedra (Figure $5 b-5 e$ ): Er1 is coordinated to two pydc ${ }^{2-}$ residues, three hydroxyl groups, and two water molecules; Er2 is coordinated instead by three pydc ${ }^{2-}$ ligands plus three hydroxyl groups and one water molecule; Er3 and
Table 5. Selected Angles (in degrees) for the Er1 and Er2 Coordination Environments Present in $\left[\mathrm{Er}_{4}(\mathrm{OH})_{4}(\mathrm{pydc})_{4}\left(\mathrm{H}_{2} \mathrm{O}\right)_{3}\right]$ • $\mathrm{H}_{2} \mathrm{O}(2)^{a}$

\begin{tabular}{|c|c|c|c|}
\hline $\mathrm{O} 1-\mathrm{Er} 1-\mathrm{O} 2$ & $68.09(9)$ & $\mathrm{O} 3-\mathrm{Er} 1-\mathrm{O} 7^{\mathrm{i}}$ & $91.84(10)$ \\
\hline $\mathrm{O} 1-\mathrm{Er} 1-\mathrm{O} 3$ & $71.72(9)$ & O3-Er1-O1W & $76.00(10)$ \\
\hline $\mathrm{O} 1-\mathrm{Er} 1-\mathrm{O} 5$ & $71.80(9)$ & $\mathrm{O} 3-\mathrm{Er} 1-\mathrm{O} 2 \mathrm{~W}$ & $143.08(9)$ \\
\hline $\mathrm{O} 1-\mathrm{Er} 1-\mathrm{O}^{\mathrm{i}}$ & $142.61(10)$ & $\mathrm{O} 3-\mathrm{Er} 1-\mathrm{N} 1$ & $143.67(10)$ \\
\hline $\mathrm{O} 1-\mathrm{Er} 1-\mathrm{O} 1 \mathrm{~W}$ & $127.84(10)$ & $\mathrm{O} 5-\mathrm{Er} 1-\mathrm{O}^{\mathrm{i}}$ & $145.58(10)$ \\
\hline $\mathrm{O} 1-\mathrm{Er} 1-\mathrm{O} 2 \mathrm{~W}$ & $80.76(9)$ & O5-Er1-O1W & $77.08(10)$ \\
\hline $\mathrm{O} 1-\mathrm{Er} 1-\mathrm{N} 1$ & $129.41(9)$ & $\mathrm{O} 5-\mathrm{Er} 1-\mathrm{O} 2 \mathrm{~W}$ & $90.82(9)$ \\
\hline $\mathrm{O} 2-\mathrm{Er} 1-\mathrm{O} 3$ & $70.68(9)$ & O5-Er1-N1 & $66.14(9)$ \\
\hline $\mathrm{O} 2-\mathrm{Er} 1-\mathrm{O} 5$ & 139.32(9) & $\mathrm{O} 7^{\mathrm{i}}-\mathrm{Er} 1-\mathrm{O} 1 \mathrm{~W}$ & 76.71(11) \\
\hline $\mathrm{O} 2-\mathrm{Er} 1-\mathrm{O}^{\mathrm{i}}$ & $74.85(9)$ & $\mathrm{O} 7^{\mathrm{i}}-\mathrm{Er} 1-\mathrm{O} 2 \mathrm{~W}$ & $95.63(10)$ \\
\hline $\mathrm{O} 2-\mathrm{Er} 1-\mathrm{O} 1 \mathrm{~W}$ & $134.85(9)$ & $\mathrm{O} 7^{\mathrm{i}}-\mathrm{Er} 1-\mathrm{N} 1$ & $83.46(10)$ \\
\hline $\mathrm{O} 2-\mathrm{Er} 1-\mathrm{O} 2 \mathrm{~W}$ & 76.53(9) & $\mathrm{O} 1 \mathrm{~W}-\mathrm{Er} 1-\mathrm{O} 2 \mathrm{~W}$ & $140.88(10)$ \\
\hline $\mathrm{O} 2-\mathrm{Er} 1-\mathrm{N} 1$ & $140.52(9)$ & O1W-Er1-N1 & $67.85(10)$ \\
\hline $\mathrm{O} 3-\mathrm{Er} 1-\mathrm{O} 5$ & 103.02(9) & $\mathrm{O} 2 \mathrm{~W}-\mathrm{Er} 1-\mathrm{N} 1$ & 73.21(10) \\
\hline $\mathrm{O} 1-\mathrm{Er} 2-\mathrm{O} 3$ & 70.77(9) & $\mathrm{O} 4-\mathrm{Er} 2-\mathrm{O} 12^{\mathrm{iii}}$ & $78.35(9)$ \\
\hline $\mathrm{O} 1-\mathrm{Er} 2-\mathrm{O} 4$ & $69.62(9)$ & $\mathrm{O} 4-\mathrm{Er} 2-\mathrm{O} 16^{\mathrm{ii}}$ & $79.09(9)$ \\
\hline $\mathrm{O} 1-\mathrm{Er} 2-\mathrm{O} 9$ & 109.49(9) & $\mathrm{O} 4-\mathrm{Er} 2-\mathrm{O} 3 \mathrm{~W}$ & $135.42(9)$ \\
\hline $\mathrm{O} 1-\mathrm{Er} 2-\mathrm{O} 12^{\mathrm{iii}}$ & $147.79(9)$ & $\mathrm{O} 4-\mathrm{Er} 2-\mathrm{N} 2^{\mathrm{iii}}$ & $136.14(9)$ \\
\hline $\mathrm{O} 1-\mathrm{Er} 2-\mathrm{O} 16^{\mathrm{ii}}$ & $88.54(9)$ & $\mathrm{O} 9-\mathrm{Er} 2-\mathrm{O} 12^{\mathrm{iii}}$ & $89.84(10)$ \\
\hline $\mathrm{O} 1-\mathrm{Er} 2-\mathrm{O} 3 \mathrm{~W}$ & $70.28(9)$ & $\mathrm{O} 9-\mathrm{Er} 2-\mathrm{O} 16^{\mathrm{ii}}$ & $146.20(9)$ \\
\hline $\mathrm{O} 1-\mathrm{Er} 2-\mathrm{N} 2^{\mathrm{iii}}$ & $143.38(9)$ & $\mathrm{O} 9-\mathrm{Er} 2-\mathrm{O} 3 \mathrm{~W}$ & 78.64(10) \\
\hline $\mathrm{O} 3-\mathrm{Er} 2-\mathrm{O} 4$ & $67.62(9)$ & $\mathrm{O} 9-\mathrm{Er} 2-\mathrm{N} 2^{\mathrm{iii}}$ & $73.02(10)$ \\
\hline $\mathrm{O} 3-\mathrm{Er} 2-\mathrm{O} 9$ & $68.63(9)$ & $\mathrm{O} 12^{\mathrm{iii}}-\mathrm{Er} 2-\mathrm{O} 16^{\mathrm{ii}}$ & $88.79(10)$ \\
\hline $\mathrm{O} 3-\mathrm{Er} 2-\mathrm{O} 12^{\mathrm{iii}}$ & $94.24(9)$ & $\mathrm{O} 12^{\mathrm{iii}}-\mathrm{Er} 2-\mathrm{O} 3 \mathrm{~W}$ & $140.68(9)$ \\
\hline $\mathrm{O} 3-\mathrm{Er} 2-\mathrm{O} 16^{\mathrm{ii}}$ & $145.13(9)$ & $\mathrm{O} 12^{\mathrm{iii}}-\mathrm{Er} 2-\mathrm{N} 2^{\mathrm{iii}}$ & $65.96(9)$ \\
\hline $\mathrm{O} 3-\mathrm{Er} 2-\mathrm{O} 3 \mathrm{~W}$ & $115.38(9)$ & $\mathrm{O} 16^{\mathrm{ii}}-\mathrm{Er} 2-\mathrm{O} 3 \mathrm{~W}$ & $81.22(10)$ \\
\hline $\mathrm{O} 3-\mathrm{Er} 2-\mathrm{N} 2^{\mathrm{iii}}$ & $136.69(9)$ & $\mathrm{O} 16^{\mathrm{ii}}-\mathrm{Er} 2-\mathrm{N} 2^{\mathrm{iii}}$ & $75.64(10)$ \\
\hline O4-Er2-O9 & 133.47(9) & $\mathrm{O} 3 \mathrm{~W}-\mathrm{Er} 2-\mathrm{N} 2^{\mathrm{iii}}$ & $74.72(9)$ \\
\hline
\end{tabular}

${ }^{a}$ Symmetry transformations used to generate equivalent atoms: (i) $-x$ $+1,-y,-z+1$; (ii) $-x+1,-y+1,-z$; (iii) $-x,-y,-z$; (iv) $-x$, $-y+1,-z+1$; (v) $-x+1,-y,-z$; (vi) $x-1, y, z$.

Er4 display similar overall coordination environments, being bonded to four pydc ${ }^{2-}$ residues and three hydroxyl groups. For all environments, while the $\mathrm{Er}-\mathrm{O}$ bond distances range from 2.290(3) to 2.411(3) $\AA$, the $\mathrm{Er}-\mathrm{N}$ distances are instead in the $2.485(3)-2.561(3) \AA$ range (Table 4); the $\mathrm{O}-\mathrm{Er}-\mathrm{O}$ and $\mathrm{O}-\mathrm{Er}-\mathrm{N}$ bond angles can be found in the 67.62(9) $-147.79(8)^{\circ}$ and $65.18(10)-145.42(9)^{\circ}$ ranges, respectively (Tables 5 and 6).

Tetrameric cubane-like clusters $\left[\mathrm{Er}_{4}\left(\mu_{3}-\mathrm{OH}\right)_{4}\right]^{8+}$ are interconnected by the pydc ${ }^{2-}$ ligands originating a neutral 3D LnOF, ${ }_{\infty}^{3}\left\{\left[\mathrm{Er}_{4}(\mathrm{OH})_{4}(\text { pydc })_{4}\left(\mathrm{H}_{2} \mathrm{O}\right)_{3}\right]\right.$, which has a brick-wall-like distribution of metallic cores in the $b c$ plane of the unit cell (Figure 6). Structural cohesion is reinforced by the presence of an extensive $\mathrm{O}-\mathrm{H} \cdots \mathrm{O}$ hydrogen bonding network (light-blue dashed lines in Figure S3, Supporting Information) involving the coordinated water molecules $(\mathrm{O} 1 \mathrm{~W}, \mathrm{O} 2 \mathrm{~W}$, and $\mathrm{O} 3 \mathrm{~W})$, the hydroxyl groups and oxygen atoms of neighboring carboxylate groups of coordinated ligands (intra-framework hydrogen bonds). In addition, the water molecule of crystallization is also engaged in hydrogen bonding interactions with the neutral network (see Table 7 for further details on the geometrical features of these interactions).

Framework Based on a Hexameric $\mathrm{Ln}^{3+}$ Cluster. Compound $\left[\mathrm{Pr}_{2}^{\mathrm{III}} \mathrm{Pr}^{\mathrm{IV}}{ }_{1.25} \mathrm{O}(\mathrm{OH})_{3}(\text { pydc })_{3}\right](3)$ crystallizes in the centrosymmetric hexagonal $R \overline{3}$ space group as revealed by single crystal XRD analysis. It is relevant to emphasize that this material can be envisaged as a true hybrid LnOF since there is a clear separation between the organic and the inorganic components in the structure as it is described in detail in the following paragraphs.

The structure is assembled by a purely inorganic hexanuclear $\operatorname{Pr}_{6}\left(\mu_{3}-\mathrm{O}\right)_{2}\left(\mu_{3}-\mathrm{OH}\right)_{6} \mid$ cluster composed by six crystallographically equivalent Pr metal centers (Pr1) located at the apexes of a regular octahedron [intermetallic Pr1 $\cdots \operatorname{Pr} 1$ distances ranging from $4.0885(2)$ to $4.2693(2) \AA]$. The lanthanides are joined 


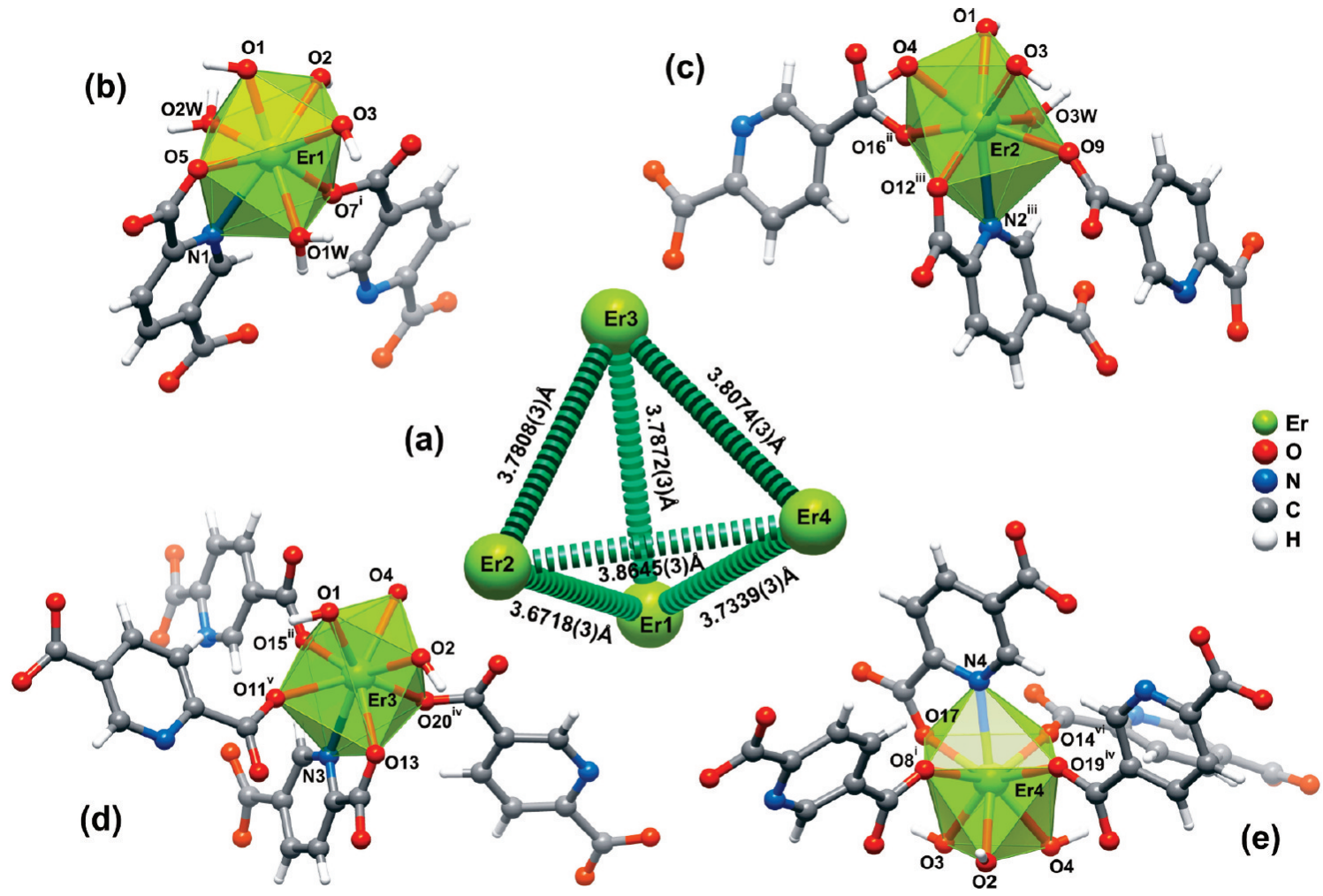

Figure 5. Structural features of the tetrametallic cluster present in $\left[\mathrm{Er}_{4}(\mathrm{OH})_{4}(\text { pydc })_{4}\left(\mathrm{H}_{2} \mathrm{O}\right)_{3}\right] \cdot \mathrm{H}_{2} \mathrm{O}($ 2), emphasizing (a) the various intermetallic distances and the coordination environments for (b) Er1, (c) Er2, (d) Er3, and (e) Er4. Atom labels are provided for all those composing the coordination spheres of the lanthanide centers. For selected bond lengths and angles see Tables 4-6. Symmetry transformations used to generate equivalent atoms: (i) $-x+1,-y,-z+1$; (ii) $-x+1,-y+1,-z$; (iii) $-x,-y,-z$; (iv) $-x,-y+1,-z+1$; (v) $-x+1,-y,-z$; (vi) $x-$ $1, y, z$.

Table 6. Selected Angles (in degrees) for the Er3 and Er4 Coordination Environments Present in $\left[\mathrm{Er}_{4}(\mathrm{OH})_{4}(\mathrm{pydc})_{4}\left(\mathrm{H}_{2} \mathrm{O}\right)_{3}\right]$. $\mathrm{H}_{2} \mathrm{O}(2)^{a}$

\begin{tabular}{|c|c|c|c|}
\hline $\mathrm{O} 1-\mathrm{Er} 3-\mathrm{O} 2$ & $70.36(9)$ & $\mathrm{O} 4-\mathrm{Er} 3-\mathrm{O} 13$ & $140.74(9)$ \\
\hline $\mathrm{O} 1-\mathrm{Er} 3-\mathrm{O} 4$ & $69.42(9)$ & $\mathrm{O} 4-\mathrm{Er} 3-\mathrm{O} 15^{\mathrm{ii}}$ & 76.94(9) \\
\hline $\mathrm{O} 1-\mathrm{Er} 3-\mathrm{O} 11^{\mathrm{v}}$ & 71.32(9) & $\mathrm{O} 4-\mathrm{Er} 3-\mathrm{O} 20^{\mathrm{iv}}$ & 79.24(9) \\
\hline $\mathrm{O} 1-\mathrm{Er} 3-\mathrm{O} 13$ & 111.17(9) & $\mathrm{O} 4-\mathrm{Er} 3-\mathrm{N} 3$ & $138.82(9)$ \\
\hline $\mathrm{O} 1-\mathrm{Er} 3-\mathrm{O} 15^{\mathrm{ii}}$ & $88.84(9)$ & $\mathrm{O} 11^{\mathrm{v}}-\mathrm{Er} 3-\mathrm{O} 13$ & 78.44(9) \\
\hline $\mathrm{O} 1-\mathrm{Er} 3-\mathrm{O} 20^{\mathrm{iv}}$ & $145.60(9)$ & $\mathrm{O} 11^{\mathrm{v}}-\mathrm{Er} 3-\mathrm{O} 15^{\mathrm{ii}}$ & $76.96(9)$ \\
\hline $\mathrm{O} 1-\mathrm{Er} 3-\mathrm{N} 3$ & 141.72(9) & $\mathrm{O} 11^{\mathrm{v}}-\mathrm{Er} 3-\mathrm{O} 20^{\mathrm{iv}}$ & $143.06(10)$ \\
\hline $\mathrm{O} 2-\mathrm{Er} 3-\mathrm{O} 4$ & $70.36(9)$ & $\mathrm{O} 11^{\mathrm{v}}-\mathrm{Er} 3-\mathrm{N} 3$ & $70.73(10)$ \\
\hline $\mathrm{O} 2-\mathrm{Er} 3-\mathrm{O} 11^{\mathrm{v}}$ & $118.70(9)$ & $\mathrm{O} 13-\mathrm{Er} 3-\mathrm{O} 15^{\mathrm{ii}}$ & $141.00(9)$ \\
\hline $\mathrm{O} 2-\mathrm{Er} 3-\mathrm{O} 13$ & $73.22(9)$ & $\mathrm{O} 13-\mathrm{Er} 3-\mathrm{O} 20^{\mathrm{iv}}$ & 84.34(10) \\
\hline $\mathrm{O} 2-\mathrm{Er} 3-\mathrm{O} 15^{\mathrm{ii}}$ & $145.68(9)$ & $\mathrm{O} 13-\mathrm{Er} 3-\mathrm{N} 3$ & $65.49(9)$ \\
\hline $\mathrm{O} 2-\mathrm{Er} 3-\mathrm{O} 20^{\mathrm{iv}}$ & $86.31(9)$ & $\mathrm{O} 15^{\mathrm{ii}}-\mathrm{Er} 3-\mathrm{O} 20^{\mathrm{iv}}$ & $97.77(10)$ \\
\hline $\mathrm{O} 2-\mathrm{Er} 3-\mathrm{N} 3$ & $134.77(9)$ & $\mathrm{O} 15^{\mathrm{ii}}-\mathrm{Er} 3-\mathrm{N} 3$ & $77.99(9)$ \\
\hline $\mathrm{O} 4-\mathrm{Er} 3-\mathrm{O} 11^{\mathrm{v}}$ & 132.71(9) & $\mathrm{O} 20^{\mathrm{iv}}-\mathrm{Er} 3-\mathrm{N} 3$ & $72.41(10)$ \\
\hline $\mathrm{O} 2-\mathrm{Er} 4-\mathrm{O} 3$ & 70.97(9) & $\mathrm{O} 4-\mathrm{Er} 4-\mathrm{O} 14^{\mathrm{vi}}$ & $74.26(9)$ \\
\hline $\mathrm{O} 2-\mathrm{Er} 4-\mathrm{O} 4$ & $68.93(8)$ & O4-Er4-O17 & $124.89(9)$ \\
\hline $\mathrm{O} 2-\mathrm{Er} 4-\mathrm{O} 8^{\mathrm{i}}$ & $72.01(9)$ & O4-Er4-O19iv & $84.90(9)$ \\
\hline $\mathrm{O} 2-\mathrm{Er} 4-\mathrm{O} 14^{\mathrm{vi}}$ & $140.34(9)$ & $\mathrm{O} 4-\mathrm{Er} 4-\mathrm{N} 4$ & $145.42(9)$ \\
\hline O2-Er4-O17 & $134.02(9)$ & $\mathrm{O} 8^{\mathrm{i}}-\mathrm{Er} 4-\mathrm{O} 14^{\mathrm{vi}}$ & $143.77(10)$ \\
\hline $\mathrm{O} 2-\mathrm{Er} 4-\mathrm{O} 19^{\mathrm{iv}}$ & 78.76(9) & $\mathrm{O} 8^{\mathrm{i}}-\mathrm{Er} 4-\mathrm{O} 17$ & 79.75(11) \\
\hline $\mathrm{O} 2-\mathrm{Er} 4-\mathrm{N} 4$ & $136.74(10)$ & $\mathrm{O} 8^{\mathrm{i}}-\mathrm{Er} 4-\mathrm{O} 19^{\mathrm{iv}}$ & $90.07(10)$ \\
\hline $\mathrm{O} 3-\mathrm{Er} 4-\mathrm{O} 4$ & $68.61(9)$ & $\mathrm{O} 8^{\mathrm{i}}-\mathrm{Er} 4-\mathrm{N} 4$ & $69.32(10)$ \\
\hline $\mathrm{O} 3-\mathrm{Er} 4-\mathrm{O} 8^{\mathrm{i}}$ & 96.44(9) & $\mathrm{O} 14^{\mathrm{vi}}-\mathrm{Er} 4-\mathrm{O} 17$ & $83.59(11)$ \\
\hline $\mathrm{O} 3-\mathrm{Er} 4-\mathrm{O} 14^{\mathrm{vi}}$ & 108.77(9) & $\mathrm{O} 14^{\mathrm{vi}}-\mathrm{Er} 4-\mathrm{O} 19^{\mathrm{iv}}$ & $83.87(10)$ \\
\hline O3-Er4-O17 & $72.26(9)$ & $\mathrm{O} 14^{\mathrm{vi}}-\mathrm{Er} 4-\mathrm{N} 4$ & $74.50(10)$ \\
\hline O3-Er4-O19iv & $145.18(9)$ & O17-Er4-O19 & $142.47(10)$ \\
\hline $\mathrm{O} 3-\mathrm{Er} 4-\mathrm{N} 4$ & $129.98(10)$ & O17-Er4-N4 & $65.18(10)$ \\
\hline $\mathrm{O} 4-\mathrm{Er} 4-\mathrm{O} 8^{\mathrm{i}}$ & $140.86(9)$ & $\mathrm{O} 19^{\mathrm{iv}}-\mathrm{Er} 4-\mathrm{N} 4$ & $77.40(10)$ \\
\hline
\end{tabular}

${ }^{a}$ Symmetry transformations used to generate equivalent atoms: (i) $-x$ $+1,-y,-z+1$; (ii) $-x+1,-y+1,-z$; (iii) $-x,-y,-z$; (iv) $-x$, $-y+1,-z+1 ;(\mathrm{v})-x+1,-y,-z$; (vi) $x-1, y, z$.

together by two $\mu_{3}$-bridging oxo groups $\left[\mathrm{Pr} 1-\mathrm{O}_{\text {охо }}\right.$ distance of $2.5785(4) \AA]$ plus six $\mu_{3}-\mathrm{OH}$ groups $\left[\mathrm{Pr} 1-\mathrm{O}_{\mathrm{OH}}\right.$ distances:

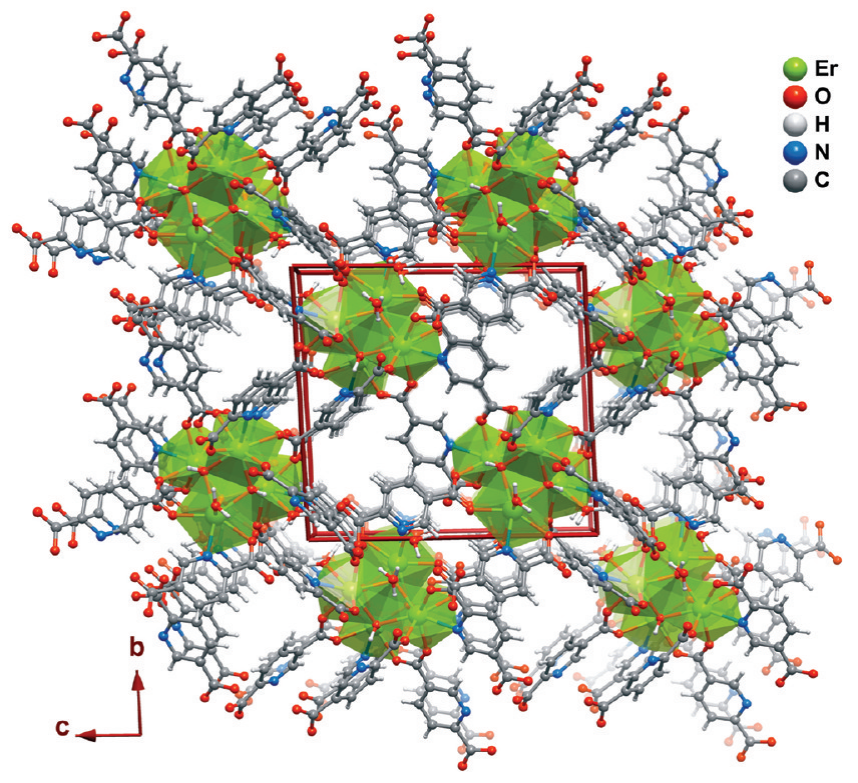

Figure 6. Mixed ball-and-stick (organic ligands and water molecules) and polyhedral $\left(\mathrm{Er}^{3+}\right.$ coordination environments) perspective view of the crystal packing of $\left[\mathrm{Er}_{4}(\mathrm{OH})_{4}(\text { pydc })_{4}\left(\mathrm{H}_{2} \mathrm{O}\right)_{3}\right] \cdot \mathrm{H}_{2} \mathrm{O}(2)$, along the [001] direction of the unit cell.

2.4404(10), 2.4585(10), and 2.4633(8) ̊̊] which cap the eight triangular faces of the metallic octahedron (Figure 7a). The resulting $\operatorname{Pr}_{6}\left(\mu_{3}-\mathrm{O}\right)_{2}\left(\mu_{3}-\mathrm{OH}\right)_{6} \mid$ cluster possesses overall $C_{3 \mathrm{i}}$ symmetry having the two oxo groups located on top of the 3 -fold axis, and can be considered as a pseudo-SBU for the construction of the framework (see below). A search in the literature 
Table 7. Hydrogen Bonding Geometry (distances in $\AA$ and angles in degrees) for $\left[\mathrm{Er}_{4}(\mathrm{OH})_{4}(\mathrm{pydc})_{4}\left(\mathrm{H}_{2} \mathrm{O}\right)_{3}\right] \cdot \mathrm{H}_{2} \mathrm{O}(2)^{a}$

\begin{tabular}{lllc}
\hline \multicolumn{1}{c}{$\mathrm{D}-\mathrm{H} \cdots \mathrm{A}$} & $d(\mathrm{H} \cdots \mathrm{A})$ & $d(\mathrm{D} \cdots \mathrm{A})$ & $\angle(\mathrm{DHA})$ \\
\hline $\mathrm{O} 1 \mathrm{~W}-\mathrm{H} 1 \mathrm{~A} \cdots \mathrm{O} 4 \mathrm{~W}$ & $1.750(19)$ & $2.666(5)$ & $163(5)$ \\
$\mathrm{O} 1 \mathrm{~W}-\mathrm{H} 1 \mathrm{~B} \cdots \mathrm{O} 18^{\mathrm{i}}$ & $1.83(4)$ & $2.778(4)$ & $170(4)$ \\
$\mathrm{O} 2 \mathrm{~W}-\mathrm{H} 2 \mathrm{~A} \cdots \mathrm{O} 13$ & $2.05(2)$ & $2.907(4)$ & $150(4)$ \\
$\mathrm{O} 2 \mathrm{~W}-\mathrm{H} 2 \mathrm{~B} \cdots \mathrm{O} 10^{\mathrm{ii}}$ & $1.73(3)$ & $2.655(4)$ & $165(4)$ \\
$\mathrm{O} 3 \mathrm{~W}-\mathrm{H} 3 \mathrm{~A} \cdots \mathrm{O} 66^{\mathrm{iii}}$ & $1.754(13)$ & $2.679(4)$ & $164(4)$ \\
$\mathrm{O} 3 \mathrm{~W}-\mathrm{H} 3 \mathrm{~B} \cdots \mathrm{O} 5$ & $1.90(2)$ & $2.764(4)$ & $150(4)$ \\
$\mathrm{O} 4 \mathrm{~W}-\mathrm{H} 4 \mathrm{~B} \cdots \mathrm{O} 17$ & $2.09(5)$ & $2.809(5)$ & $131(5)$ \\
$\mathrm{O} 4 \mathrm{~W}-\mathrm{H} 4 \mathrm{~B} \cdots \mathrm{O} 18$ & $2.53(4)$ & $3.237(5)$ & $130(4)$ \\
${ }^{a}$ Symmetry transformations used to generate equivalent atoms: (i) \\
$-x,-y,-z+1 ;$ (ii) $x+1, y, z ;$ (iii) $-x+1,-y,-z+1$.
\end{tabular}

and in the CSD reveals the existence of only a handful of materials whose crystalline structures either contain or are solely composed of related hexanuclear $\left[\operatorname{Ln}_{6}\left(\mu_{3}-\mathrm{O}\right)_{6}\right]$ cores. ${ }^{31}$ Hence this material is also truly unprecedented being the first example of a modular LnOF incorporating this hexanuclear cluster which, noteworthy, is reminiscent from the structure of the mixedvalence $\mathrm{Pr}_{12} \mathrm{O}_{22}$ oxide (Figure $7 \mathrm{~b}$ ). ${ }^{32}$

There are two crystallographically independent lanthanide centers in 3: while Pr1 originates the aforementioned hexanuclear cluster, Pr2 (only half-occupied) is instead positioned in-between two neighboring clusters, establishing a physical connection between inorganic cores along the [001] direction of the unit cell (Figure $8 \mathrm{~b}$ ). $\operatorname{Pr} 1$ is coordinated by two symmetry equivalent $\mathrm{O}$-atoms of the bridging oxo groups $\left(\mu_{3}-\mathrm{O}_{\text {oxo }}\right)$, two symmetry-related $\mathrm{O}$-atoms from bridging hydroxyl groups $\left(\mu_{3^{-}}\right.$ $\left.\mathrm{O}_{\mathrm{OH}}\right)$, four crystallographic distinct $\mathrm{O}$-atoms and one $\mathrm{N}$-atom from the pydc ${ }^{2-}$ ligand, in a typical $\left\{\mathrm{PrNO}_{8}\right\}$ nine-coordination fashion whose geometry resembles a considerably distorted tricapped trigonal prism (Figure 7c): on the one hand, while the $\operatorname{Pr} 1-\mathrm{O}$ bond distances can be found in the 2.3956(11)2.5785(4) A range, the Pr1-N distance is considerably longer and of 2.7764(10) $\AA$ (Table 8); on the other, the internal angles just concerning either the capping positions or the two triangular bases are considerably spread over the $96.25(5)-137.96(3)^{\circ}$ and $68.94(3)-81.86(5)^{\circ}$ ranges, respectively, which clearly reflects the high degree of distortion of the polyhedron (Table 9). The coordination environment of the partially occupied Pr2 lanthanide center is instead solely composed by oxygen atoms arising from two and six symmetry-related oxo and carboxylate groups, respectively, defining a eight-coordinated geometry $\left\{\mathrm{PrO}_{8}\right\}$ which resembles a slightly distorted cube commonly found among typical inorganic structures but unusual for LnOF materials (Figure 8d; Tables 8 and 9). The crystallographically single pydc ${ }^{2-}$ organic ligand is connected to four symmetryrelated $\operatorname{Pr} 1$ centers and to one $\operatorname{Pr} 2$ center via the coordination modes depicted in Scheme 1d: syn,syn-bridges (mode I) contribute to the formation of the hexameric cluster; the heteroatom of the aromatic ring and $\mathrm{O} 3$ of the adjacent carboxylate group forms a typical $\mathrm{N}, \mathrm{O}$-chelate (mode II) with a Pr1 lanthanide [Figure 7c; bite angle being of about $60.4^{\circ}$ ]; this chelate is coupled to a skew-unidentate connected with another Pr1(mode VI), while the other oxygen atom of the carboxylate is involved in a syn-unidentate connection (mode V).

The intercluster connectivity along the [001] direction of the unit cell is ensured by the Pr2 cation which creates inorganic chains (Figure 8a) randomly interrupted due to the partial occupancy of this center. Nevertheless, it is noteworthy that these chains share some structural similarities with the mixedvalence $\operatorname{Pr}_{12} \mathrm{O}_{22}$ oxide: ${ }^{32}$ while in $\mathbf{3}$ these hexameric clusters are intercalated by charge-balancing $\mathrm{Pr}^{3+}$ cations, in the inorganic compound the clusters coalesce into a dense phase; nevertheless, it is still discernible the presence of chains in this inorganic material, having the hexameric clusters directly connected via oxo groups (Figure $8 \mathrm{~b}$ ). Interchain connectivity in 3 is ensured via the organic pydc ${ }^{2-}$ ligand, ultimately originating a three-dimensional LnOF framework, $\infty^{3}\left\{\left[\mathrm{Pr}^{\mathrm{III}} 2^{-}\right.\right.$ $\left.\left.\operatorname{Pr}^{\mathrm{IV}}{ }_{1.25} \mathrm{O}(\mathrm{OH})_{3}(\text { pydc })_{3}\right]\right\}$, having small rectangular channels running parallel to the $c$-axis of the unit cell (Figure 9). Even though these channels are too small to allow the inclusion of solvent molecules, their existence seems to facilitate the partial inclusion of oxygen from the surrounding environment as observed during the thermoanalytical studies (see Thermal Analyses subsection).

Topological Studies. These 3D lanthanide-organic materials can be more conveniently described using a typical topological approach in which the networks are simplified to central nodes and bridging rods. ${ }^{2,33,34}$ This procedure, based on pure mathematical concepts applied to crystal chemistry (the chemical properties of the individual building blocks are not taken into consideration and only connectivity is analyzed), yields the immediate taxonomy of the frameworks thus allowing a direct comparison of the isolated materials with other related structures available in the literature, either synthesized or predicted from theory. 3,35

As a consequence of the structural complexity of the frameworks (see previous subsections for details), it is significantly more convenient, and also chemically more accurate, to consider the dimeric, tetrameric, and hexameric units as the central nodes of the nets (the center of gravity of each unit is considered as the node), ultimately reducing the frameworks to uninodal nets. Since these centrosymmetric units are interlinked via the pydc ${ }^{2-}$ bridging ligands, each connection via this organic ligand is thus considered as a connecting rod. It is of considerable importance to emphasize that other nodes for the networks could be considered, in particular each crystallographically independent lanthanide center. However, such procedure would lead to high-order, and more complex, networks types (e.g., fournodal and binodal for materials 2 and 3, respectively). All topological studies were performed using the software package TOPOS, ${ }^{36}$ and representative schematic drawings are provided in Supporting Information (Figures S5, S6, and S7).

3D lanthanide-organic compounds based on the centrosymmetric dimeric units (family 1) are uninodal 4-connected nets (Figure S5a, Supporting Information) with a topology identical to that of diamond (Schäfli symbol $6^{6}$ - Figure S5b, Supporting Information). The increasing of the centrosymmetric units is clearly accompanied by an increase in overall connectivity of the uninodal nets: compounds $\mathbf{2}$ and $\mathbf{3}$ (having tetrameric and hexameric central nodes, respectively) are instead 8- (Figure S6a, Supporting Information) and 14-connected (Figure S7a, Supporting Information) networks with Schäfli symbols $3^{6} .4^{14} \cdot 5^{8}$ (Figure S6b, Supporting Information) and $3^{36} \cdot 4^{48} \cdot 5^{7}$ (Figure S7b, Supporting Information), respectively. Searches in the Reticular Chemistry Structure Resource (RCSR) $)^{37}$ and in EPINET ${ }^{38}$ reveal that the nodal connectivity of $\mathbf{2}$ is 8 -fold and reminiscent of that present in the known structure type bct. To the best of our knowledge, the overall connectivity for $\mathbf{3}$ is uncommon among MOF structures and identical to that of network bcu-x (referenced as sqc38 in the EPINET), ${ }^{37}$ which is the dual network type of the sodalite structure but considering the packing of congruent tetrahedra instead of octahedra. ${ }^{34}$ This topology can be envisaged as derived from a body-centered cubic lattice (which is 8-connected) but also considering the second neighbors.

Vibrational Spectroscopy. Vibrational (FT-IR and FTRaman) spectroscopy studies of the 3D modular frameworks 1 

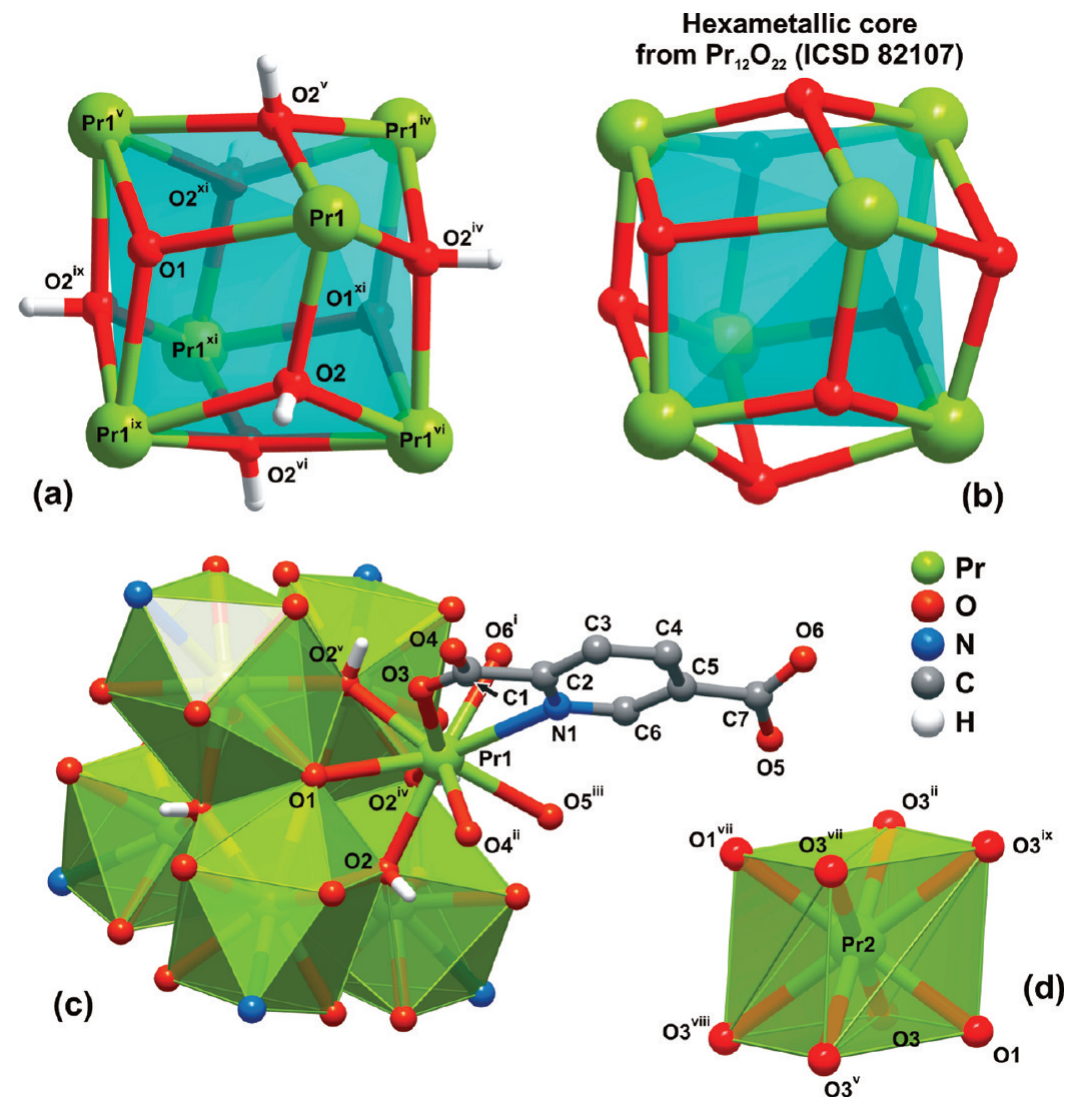

(d)

Figure 7. Comparative structural representation of the praseodymium hexameric cores present in (a) $\left[\operatorname{Pr}_{2}^{\mathrm{III}} \operatorname{Pr}^{\mathrm{IV}}{ }_{1.25} \mathrm{O}(\mathrm{OH})_{3}(\mathrm{pydc})_{3}\right](3)$ and in the $(\mathrm{b})$ mixed-valence $\operatorname{Pr}_{12} \mathrm{O}_{22}$ oxide. (c) Magnification of the hexameric $\operatorname{Pr}_{6}\left(\mu_{3}-\mathrm{O}\right)_{2}\left(\mu_{3}-\mathrm{OH}\right)_{6}$ l cluster emphasizing the tricapped trigonal prismatic coordination environment of Pr1. (d) Polyhedral representation of the distorted $\left\{\mathrm{PrO}_{8}\right\}$ cuboidal coordination geometry of Pr2. Symmetry transformations used to generate equivalent atoms: (i) $-y+2 / 3, x-y+1 / 3, z+1 / 3$; (ii) $x-y, x,-z$; (iii) $-x+1 / 3,-y+2 / 3,-z+2 / 3$; (iv) $y,-x+y,-z+1$; (v) $-x+y,-x$, $z$; (vi) $x-y, x,-z+1$; (vii) $-x,-y,-z$; (viii) $y,-x+y,-z$; (ix) $-y, x-y, z$; (x) $-x+y+1 / 3,-x+2 / 3, z-1 / 3$; (xi) $-x$, $-y,-z+1$.

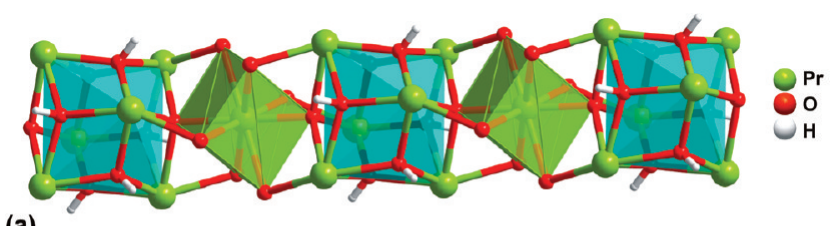

(a)

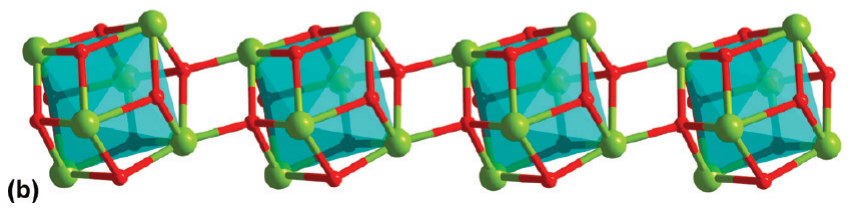

Figure 8. Intercluster connectivity in (a) $\left[\mathrm{Pr}^{\mathrm{III}}{ }_{2} \mathrm{Pr}^{\mathrm{IV}}{ }_{1.25} \mathrm{O}(\mathrm{OH})_{3}(\mathrm{pydc})_{3}\right]$ (3) and (b) the mixed-valence $\operatorname{Pr}_{12} \mathrm{O}_{22}$ oxide: while in $\mathbf{3} \operatorname{Pr} 2$ centers establish the physical links between clusters, in the later inorganic compound clusters are directly connected via oxo groups.

to $\mathbf{3}$ clearly support the structural features unveiled by the XRD studies (see Figures S9 and S10, Supporting Information). The spectral regions found in the $3600-2300 \mathrm{~cm}^{-1}$ (associated with the $\mathrm{O}-\mathrm{H}$ stretching and $\mathrm{N}-\mathrm{H}$ vibrational modes) and $1700-1300$ $\mathrm{cm}^{-1}$ ranges (vibrational modes associated with the carboxylate groups) are particularly informative as they contain diagnostic bands which clearly support the structural details of the different coordination modes of $\mathrm{H}_{2-x}$ pydc $^{x-}$ residues. ${ }^{39}$

FT-IR spectra contain a broadband in the $3600-3400 \mathrm{~cm}^{-1}$ region attributed to the simultaneous appearance of $v(\mathrm{O}-\mathrm{H})$ stretching vibrational modes from water molecules and hydroxyl
Table 8. Selected Bond Lengths (in $\AA$ ) for the Pr1 and Pr2 Coordination Environments Present in $\left[\mathrm{Pr}^{\mathrm{II}}{ }_{2} \mathrm{Pr}^{\mathrm{IV}}{ }_{1.25} \mathrm{O}(\mathrm{OH})_{3}(\mathrm{pydc})_{3}\right](3)^{a}$

\begin{tabular}{|c|c|c|c|}
\hline $\operatorname{Pr} 1-06^{\mathrm{i}}$ & $2.3956(11)$ & $\operatorname{Pr} 2-\mathrm{O} 1$ & $2.2853(13)$ \\
\hline $\mathrm{Pr} 1-\mathrm{O} 4^{\mathrm{ii}}$ & $2.4400(9)$ & $\operatorname{Pr} 2-01^{\text {vii }}$ & $2.2853(13)$ \\
\hline $\mathrm{Pr} 1-\mathrm{O} 2$ & $2.4405(9)$ & $\mathrm{Pr} 2-\mathrm{O} 3$ & $2.5768(10)$ \\
\hline $\mathrm{Pr} 1-\mathrm{O} 5^{\mathrm{iii}}$ & $2.4580(10)$ & $\mathrm{Pr} 2-\mathrm{O}^{\mathrm{ii}}$ & $2.5768(10)$ \\
\hline $\operatorname{Pr} 1-\mathrm{O} 2^{\mathrm{iv}}$ & $2.4585(9)$ & $\mathrm{Pr} 2-\mathrm{O}^{\mathrm{v}}$ & $2.5768(10)$ \\
\hline $\operatorname{Pr} 1-\mathrm{O} 2^{\mathrm{v}}$ & $2.4633(9)$ & $\operatorname{Pr} 2-\mathrm{O}^{\text {vii }}$ & $2.5768(10)$ \\
\hline $\mathrm{Pr} 1-\mathrm{O} 3$ & $2.4964(9)$ & $\operatorname{Pr} 2-\mathrm{O}^{\text {viii }}$ & $2.5768(10)$ \\
\hline $\operatorname{Pr} 1-\mathrm{O} 1$ & $2.5785(4)$ & $\operatorname{Pr} 2-\mathrm{O}^{\mathrm{ix}}$ & $2.5768(10)$ \\
\hline $\operatorname{Pr} 1-\mathrm{N} 1$ & $2.7764(10)$ & & \\
\hline
\end{tabular}

${ }^{a}$ Symmetry transformations used to generate equivalent atoms: (i) $-y$ $+2 / 3, x-y+1 / 3, z+1 / 3$; (ii) $x-y, x,-z$; (iii) $-x+1 / 3,-y+2 /$ $3,-z+2 / 3$; (iv) $y,-x+y,-z+1$; (v) $-x+y,-x$, z; (vi) $x-y, x$, $-z+1$; (vii) $-x,-y,-z$; (viii) $y,-x+y,-z$; (ix) $-y, x-y, z$; (x) $-x+y+1 / 3,-x+2 / 3, z-1 / 3$.

groups involved in the hydrogen bonds. The existence of these two different types of chemical species is evident in the spectrum of compound $\mathbf{2}$ which shows three markedly distinct bands centered at 3520,3405 , and $3238 \mathrm{~cm}^{-1}$. In the spectra of compounds 1a and 1b there are several bands in the 3100-2400 $\mathrm{cm}^{-1}$ region which arise from the presence of the chargebalancing $\left(\mathrm{CH}_{3}\right)_{2} \mathrm{NH}_{2}{ }^{+}$cation: on the one hand, mediumintensity (and broad) bands peaking at about $2780 \mathrm{~cm}^{-1}$ can be attributed to the $v(\mathrm{C}-\mathrm{H})$ stretching vibration of the $\mathrm{N}-\mathrm{C}-\mathrm{H}$ groups; on the other, the bands centered at $c a .2475 \mathrm{~cm}^{-1}$ arise from the $v\left(\mathrm{~N}-\mathrm{H}^{+}\right)$stretching modes.

The various coordination modes adopted by the carboxylate groups in all compounds are clear from the FT-IR spectra. Indeed, the typical antisymmetric and symmetric stretching 
Table 9. Selected Angles (in degrees) for the Pr1 and Pr2 Coordination Environments Present in $\left[\mathrm{Pr}^{\mathrm{III}}{ }_{2} \mathrm{Pr}^{\mathrm{IV}}{ }_{1.25} \mathrm{O}(\mathrm{OH})_{3}(\mathrm{pydc})_{3}\right](3)^{a}$

\begin{tabular}{|c|c|c|c|}
\hline $\mathrm{O} 1-\mathrm{Pr} 1-\mathrm{O} 2$ & $63.36(3)$ & $\mathrm{O} 2^{\mathrm{iv}}-\operatorname{Pr} 1-\mathrm{O} 5^{\mathrm{iii}}$ & 76.94(3) \\
\hline $\mathrm{O} 1-\operatorname{Pr} 1-\mathrm{O} 2^{\mathrm{iv}}$ & $98.73(4)$ & $\mathrm{O} 2^{\mathrm{iv}}-\operatorname{Pr} 1-\mathrm{O}^{\mathrm{i}}$ & $78.66(4)$ \\
\hline $\mathrm{O} 1-\operatorname{Pr} 1-\mathrm{O} 2^{\mathrm{v}}$ & $63.06(3)$ & $\mathrm{O} 2^{\mathrm{iv}}-\operatorname{Pr} 1-\mathrm{N} 1$ & $133.88(3)$ \\
\hline $\mathrm{O} 1-\mathrm{Pr} 1-\mathrm{O} 3$ & $68.94(3)$ & $\mathrm{O} 2^{\mathrm{v}}-\mathrm{Pr} 1-\mathrm{O} 3$ & $86.28(3)$ \\
\hline $\mathrm{O} 1-\operatorname{Pr} 1-\mathrm{O} 4^{\mathrm{ii}}$ & $80.65(3)$ & $\mathrm{O} 2^{\mathrm{v}}-\mathrm{Pr} 1-\mathrm{O} 4^{\mathrm{ii}}$ & $142.50(3)$ \\
\hline $\mathrm{O} 1-\operatorname{Pr} 1-\mathrm{O} 5^{\mathrm{iii}}$ & $144.47(3)$ & $\mathrm{O} 2^{\mathrm{v}}-\mathrm{Pr} 1-\mathrm{O} 5^{\mathrm{iii}}$ & $137.83(3)$ \\
\hline $\mathrm{O} 1-\operatorname{Pr} 1-\mathrm{O}^{\mathrm{i}}$ & $132.50(4)$ & $\mathrm{O} 2^{\mathrm{v}}-\operatorname{Pr} 1-\mathrm{O} 6^{\mathrm{i}}$ & $73.56(4)$ \\
\hline $\mathrm{O} 1-\mathrm{Pr} 1-\mathrm{N} 1$ & $126.73(3)$ & $\mathrm{O} 2^{\mathrm{v}}-\operatorname{Pr} 1-\mathrm{N} 1$ & $125.32(3)$ \\
\hline $\mathrm{O} 2-\operatorname{Pr} 1-\mathrm{O} 2^{\mathrm{iv}}$ & $65.45(3)$ & $\mathrm{O} 3-\operatorname{Pr} 1-\mathrm{O} 4^{\mathrm{ii}}$ & $71.35(3)$ \\
\hline $\mathrm{O} 2-\mathrm{Pr} 1-\mathrm{O} 2^{\mathrm{v}}$ & $96.25(5)$ & $\mathrm{O} 3-\mathrm{Pr} 1-\mathrm{O}^{\mathrm{iii}}$ & $128.38(3)$ \\
\hline $\mathrm{O} 2-\mathrm{Pr} 1-\mathrm{O} 3$ & $124.24(3)$ & $\mathrm{O} 3-\operatorname{Pr} 1-\mathrm{O}^{\mathrm{i}}$ & $90.69(4)$ \\
\hline $\mathrm{O} 2-\operatorname{Pr} 1-\mathrm{O} 4^{\mathrm{ii}}$ & 73.98(4) & $\mathrm{O} 3-\operatorname{Pr} 1-\mathrm{N} 1$ & $60.42(3)$ \\
\hline $\mathrm{O} 2-\mathrm{Pr} 1-\mathrm{O} 5^{\mathrm{iii}}$ & $83.48(3)$ & $\mathrm{O} 4^{\mathrm{ii}}-\mathrm{Pr} 1-\mathrm{O} 5^{\mathrm{iii}}$ & $78.07(4)$ \\
\hline $\mathrm{O} 2-\operatorname{Pr} 1-\mathrm{O}^{\mathrm{i}}$ & $143.44(4)$ & $\mathrm{O} 4^{\mathrm{ii}}-\operatorname{Pr} 1-\mathrm{O} 6^{\mathrm{i}}$ & $134.25(4)$ \\
\hline $\mathrm{O} 2-\mathrm{Pr} 1-\mathrm{N} 1$ & $137.96(3)$ & $\mathrm{O} 4^{\mathrm{ii}}-\mathrm{Pr} 1-\mathrm{N} 1$ & $68.98(4)$ \\
\hline $\mathrm{O} 2^{\mathrm{iv}}-\operatorname{Pr} 1-\mathrm{O} 2^{\mathrm{v}}$ & $65.11(3)$ & $\mathrm{O} 5^{\mathrm{iii}}-\operatorname{Pr} 1-\mathrm{O} 6^{\mathrm{i}}$ & $81.86(5)$ \\
\hline $\mathrm{O} 2^{\mathrm{iv}}-\mathrm{Pr} 1-\mathrm{O} 3$ & 151.21(3) & $\mathrm{O}^{\mathrm{iii}}-\mathrm{Pr} 1-\mathrm{N} 1$ & $70.23(3)$ \\
\hline $\mathrm{O} 2^{\mathrm{iv}}-\operatorname{Pr} 1-\mathrm{O} 4^{\mathrm{ii}}$ & $134.10(3)$ & $\mathrm{O}^{\mathrm{i}}-\mathrm{Pr} 1-\mathrm{N} 1$ & $65.60(3)$ \\
\hline $\mathrm{O} 1-\mathrm{Pr} 2-\mathrm{O} 1^{\mathrm{vii}}$ & 180.00 & $\mathrm{O} 3-\mathrm{Pr} 2-\mathrm{O}^{\mathrm{v}}$ & $111.054(19)$ \\
\hline $\mathrm{O} 1-\operatorname{Pr} 2-\mathrm{O} 3$ & $72.16(2)$ & $\mathrm{O} 3-\mathrm{Pr} 2-\mathrm{O}^{\mathrm{vii}}$ & $180.00(8)$ \\
\hline $\mathrm{O} 1-\mathrm{Pr} 2-\mathrm{O}^{\mathrm{ii}}$ & 107.84(2) & $\mathrm{O} 3^{\mathrm{ii}}-\operatorname{Pr} 2-\mathrm{O}^{\mathrm{v}}$ & $180.00(4)$ \\
\hline $\mathrm{O} 3-\mathrm{Pr} 2-\mathrm{O}^{\mathrm{ii}}$ & $68.946(19)$ & & \\
\hline
\end{tabular}

${ }^{a}$ Symmetry transformations used to generate equivalent atoms: (i) $-y$ $+2 / 3, x-y+1 / 3, z+1 / 3$; (ii) $x-y, x,-z$; (iii) $-x+1 / 3,-y+2 /$ $3,-z+2 / 3$; (iv) $y,-x+y,-z+1$; (v) $-x+y,-x, z$; (vi) $x-y, x$, $-z+1$; (vii) $-x,-y,-z$; (viii) $y,-x+y,-z$; (ix) $-y, x-y, z$; (x) $-x+y+1 / 3,-x+2 / 3, z-1 / 3$.

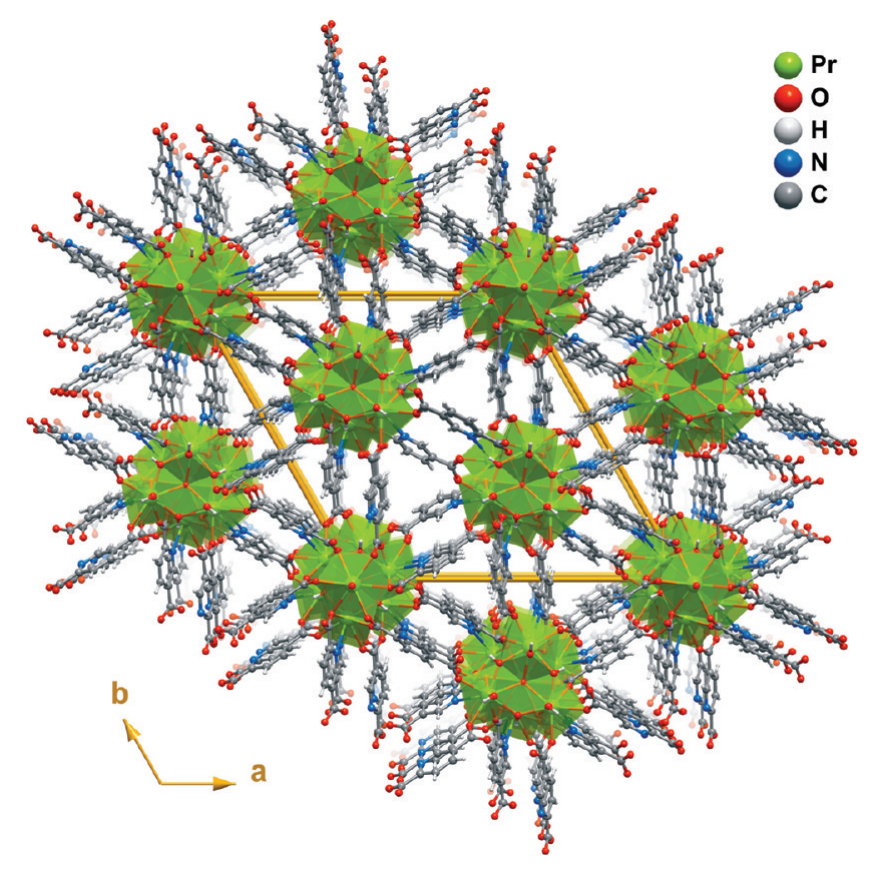

Figure 9. Mixed ball-and-stick (organic ligands and water molecules) and polyhedral $\left(\mathrm{Pr}^{3+}\right.$ coordination environments) perspective view of the crystal packing of $\left[\mathrm{Pr}_{2}{ }_{2} \mathrm{Pr}^{\mathrm{IV}}{ }_{1.25} \mathrm{O}(\mathrm{OH})_{3}(\text { pydc })_{3}\right](3)$, along the [001] direction of the unit cell.

bands for coordinated carboxylate anions are markedly present, appearing in the $1680-1550$ and $1450-1320 \mathrm{~cm}^{-1}$ regions, respectively, which correspond to $\Delta\left[v_{\text {asym }}\left(-\mathrm{CO}_{2}{ }^{-}\right)-v_{\text {sym }}(-\right.$ $\left.\mathrm{CO}_{2}^{-}\right)$] values in the $360-100 \mathrm{~cm}^{-1}$ range, which agree well with those expected for the coordination fashions described in the previous sections. ${ }^{40}$

A number of intense and sharp bands in the $1200-500 \mathrm{~cm}^{-1}$ spectral region common to all compounds are indicative of the presence of 2,5-disubstituted pyridine rings (e.g., $\delta(\mathrm{C}-\mathrm{H})$ deformation modes for the bands centered at $c a .825$ and 770 $\left.\mathrm{cm}^{-1}\right)$. The aromatic $v(\mathrm{C}-\mathrm{H})$ stretching vibrational modes are also evident for all compounds with a number of bands found in the $3100-3000 \mathrm{~cm}^{-1}$ region.

Thermal Analyses. Thermograms from ambient temperature up to $700{ }^{\circ} \mathrm{C}$ for compounds $\mathbf{1 - 3}$ are provided in Figure S8, Supporting Information. These studies are particularly informative regarding the water content of the synthesized materials and, for the case of compounds belonging to family $\mathbf{1}$, were of great importance to help in the quantification of the water content present in the solvent accessible area of the 3D frameworks (see Experimental Section dedicated to singlecrystal XRD). From ambient temperature up to $c a .200{ }^{\circ} \mathrm{C}$, compounds $\mathbf{1 a}$ and $\mathbf{1 b}$ release about $2.5 \%$ and $2.1 \%$, respectively, fairly agreeing with the release of half-water molecule per lanthanide center (calculated weight losses of about $1.7 \%$ and $1.6 \%$, respectively). These results are in line with the structural conclusions derived from vibrational spectroscopy studies (see previous section) and CHN elemental analyses. After $200{ }^{\circ} \mathrm{C}$ thermal decomposition starts to settle in through several consecutive steps leading to final residues of about $31.4 \%$ and $34.7 \%$ for $\mathbf{1 a}$ and $\mathbf{1 b}$, respectively, which are in good agreement with the expected values for the formation of the stoichiometric amounts of the lanthanide oxides (calculated: $32.8 \%$ and $34.6 \%$ ).

Compound 2 loses very gradually both the water molecule of crystallization and those coordinated to the lanthanide centers in the $160-400{ }^{\circ} \mathrm{C}$ temperature range, with a total weight loss of about $5.2 \%$ (calculated value for four water molecules of ca. $4.9 \%$ ). Above this temperature there is a small decrease in mass before $455{ }^{\circ} \mathrm{C}$ which may be attributable to the release of a small amount of water molecules arising from the bridging hydroxyl groups composing the tetrameric cubane-like $\left[\operatorname{Er}_{4}\left(\mu_{3^{-}}\right.\right.$ $\left.\mathrm{OH})_{4}\right]^{8+}$ core. The oxidation of the organic component settles in after $455^{\circ} \mathrm{C}$ leading to a final residue (observed value of $c a$. $51.2 \%$ ) which agrees well with that expected for the formation of the stoichiometric quantity of $\mathrm{Er}_{2} \mathrm{O}_{3}$ (calculated of ca. 52.1\%).

The thermal behavior of compound $\mathbf{3}$ is remarkably unique and, to the best of our knowledge, reflects an unprecedented structural feature among LnOFs. Between ambient temperature and approximately $450{ }^{\circ} \mathrm{C}$ the sample in study increases its mass by $c a .2 .7 \%$. A plausible explanation for this unusual feature can be attributed to the uptake of oxygen from the surrounding environment along the channels running parallel to the $c$-axis into the praseodymium oxide inorganic core (Figure 8). Indeed, on the one hand, the existence of several different stable phases of praseodymium oxide ${ }^{27}$ allows a relatively easy modification of the oxidation state of the metallic center and, on the other, it is also known that $\operatorname{Pr}_{2} \mathrm{O}_{3}$ can be employed as an oxygenstorage component in catalysis. ${ }^{41}$ In the $500-600{ }^{\circ} \mathrm{C}$ temperature range the material undergoes thermal decomposition, most probably via the oxidation of the organic component. The mass of the residue at about $600{ }^{\circ} \mathrm{C}$ is of $60.8 \%$ of the initial weight. This value agrees fairly well with the formation of the stoichiometric amount of $\operatorname{Pr}_{6} \mathrm{O}_{4}(\mathrm{OH})_{14}$ which, on the one hand, exhibits the same average charge per lanthanide center as that found in the most stable praseodymium oxide, $\operatorname{Pr}_{6} \mathrm{O}_{11}(+3.67)$; on the other, it retains the overall geometry of the hexameric core depicted in Figure 7 which constitutes the SBU unit of compound 3 with the vacant coordination positions of the organic ligands being instead occupied by hydroxyl groups.

\section{Conclusion}

In this study we have demonstrated that a modification of the reactive conditions for the $\mathrm{H}_{2}$ pydc-lanthanide system leads to distinct modular framework materials exhibiting different topologies and remarkably distinct building units: on the one 
hand, typical solvothermal conditions lead to the solvolysis of DMF, originating in situ $\left(\mathrm{CH}_{3}\right)_{2} \mathrm{NH}_{2}{ }^{+}$cations which promote the formation of anionic frameworks build-up from centrosymmetric dimers, $\left(\mathrm{CH}_{3}\right)_{2} \mathrm{NH}_{2}\left[\mathrm{Ln}(\text { pydc })_{2}\right] \cdot 1 / 2 \mathrm{H}_{2} \mathrm{O}\left[\mathrm{Ln}^{3+}=\mathrm{Eu}^{3+}\right.$ (1a) or $\mathrm{Er}^{3+}$ (1b)]; on the other hand, under hydrothermal conditions we observed the unexpected clustering of lanthanide centers into unprecedented tetrameric $\left[\mathrm{Er}_{4}\left(\mu_{3}-\mathrm{OH}\right)_{4}\right]^{8+}$ and hexameric $\operatorname{Pr}_{6}\left(\mu_{3}-\mathrm{O}\right)_{2}\left(\mu_{3}-\mathrm{OH}\right)_{6}$ l centrosymmetric units which act as the building blocks of the resulting frameworks, $\left[\mathrm{Er}_{4}(\mathrm{OH})_{4^{-}}\right.$ (pydc) $\left.)_{4}\left(\mathrm{H}_{2} \mathrm{O}\right)_{3}\right] \cdot \mathrm{H}_{2} \mathrm{O}(\mathbf{2})$ and $\left[\mathrm{Pr}^{\mathrm{III}}{ }_{2} \mathrm{Pr}^{\mathrm{IV}}{ }_{1.25} \mathrm{O}(\mathrm{OH})_{3}(\mathrm{pydc})_{3}\right](\mathbf{3})$, respectively. At present we are investigating in our laboratories the possibility to obtain different modular materials containing lanthanide centers and $\mathrm{H}_{2-x}$ pydc ${ }^{x-}$ residues. On the basis of the results presented in this manuscript, we are particularly interested in the study of the oxygen uptake by the inorganic core present in compound $\mathbf{3}$ and the possibility to use this material as a precursor for the isolation of nanosized functional lanthanideclusters.

Acknowledgment. We are grateful to Fundação para a Ciência e a Tecnologia (Portugal) for their general financial support (PPCDT/QUI/58377/2004 and PTDC/QUI/65805/2006 supported by FEDER), the postdoctoral scholarships Nos. SFRH/BPD/9309/2002 (to F.-N.S.) and SFRH/BPD/34895/2007 (to L.C.-S.), and for funding towards the purchase of the singlecrystal diffractometer.

Supporting Information Available: Additional structural drawings for structures 1-3 showing details of the hydrogen bonding networks and the network topological representations. Thermograms, FT-IR, and FT-Raman spectra for all compounds. This material is available free of charge via the Internet at http://pubs.acs.org.

\section{References}

(1) (a) Champness, N. R. Making Coordination Frameworks. In Making Crystals by Design - Methods, Techniques and Applications, 1st ed.; Braga, D.; Grepioni, F., Eds.; Wiley-VCH Verlag GmbH \& Co. KGaA: Weinheim, 2007; pp 193-208; (b) Zhang, G. Q.; Yang, G. Q.; Ma, J. S. Cryst. Growth Des. 2006, 6, 933-939. (c) Devic, T.; Serre, C.; Audebrand, N.; Marrot, J.; Ferey, G. J. Am. Chem. Soc. 2005, 127 , 12788-12789. (d) Férey, G.; Mellot-Draznieks, C.; Serre, C.; Millange, F.; Dutour, J.; Surble, S.; Margiolaki, I. Science 2005, 309, 20402042. (e) Guillou, O.; Daiguebonne, C. Lanthanide-containing Coordination Polymers. In Handbook on the Physics and Chemistry of Rare Earths; Gschneidner, K. A.; Bunzli, J.-C. G.; Pecharsky, V. K., Eds.; Elsevier B. V.: Amsterdam, 2005; Vol. 34, pp 359-404; (f) Kitagawa, S.; Uemura, K Chem. Soc. Rev. 2005, 34, 109-119. (g) Livage, C.; Guillou, N.; Chaigneau, J.; Rabit, P.; Drillon, M.; Férey, G. Angew. Chem.-Int. Ed. 2005, 44, 6488-6491. (h) Matczak-Jon, E.; VidenovaAdrabinska, V. Coord. Chem. Rev. 2005, 249, 2458-2488. (i) Ye, B. H.; Tong, M. L.; Chen, X. M. Coord. Chem. Rev. 2005, 249, 545565. (j) Janiak, C. Dalton Trans. 2003, 2781-2804. (k) Kesanli, B.; Lin, W. B. Coord. Chem. Rev. 2003, 246, 305-326. (1) Papaefstathiou, G. S.; MacGillivray, L. R. Coord. Chem. Rev. 2003, 246, 169-184.

(2) (a) Carlucci, L.; Ciani, G.; Proserpio, D. M. Coord. Chem. Rev. 2003 246, 247-289. (b) Carlucci, L.; Ciani, G.; Proserpio, D. M. CrystEngComm 2003, 5, 269-279.

(3) Batten, S. R.; Robson, R. Angew. Chem., Int. Ed. 1998, 37, 14611494.

(4) (a) Chui, S. S. Y.; Lo, S. M. F.; Charmant, J. P. H.; Orpen, A. G.; Williams, I. D. Science 1999, 283, 1148-1150. (b) Evans, O. R.; Ngo, H. L.; Lin, W. B. J. Am. Chem. Soc. 2001, 123, 10395-10396. (c) Fujita, M.; Kwon, Y. J.; Washizu, S.; Ogura, K. J. Am. Chem. Soc. 1994, 116, 1151-1152. (d) Seo, J. S.; Whang, D.; Lee, H.; Jun, S. I.; Oh, J.; Jeon, Y. J.; Kim, K. Nature 2000, 404, 982-986. (e) Bonnet, F.; Visseaux, M.; Pereira, A.; Bouver, F.; Barbier-Baudry, D. Macromol. Rapid Commun. 2004, 25, 873-877.

(5) (a) Eddaoudi, M.; Kim, J.; Rosi, N.; Vodak, D.; Wachter, J.; O'Keefe, M.; Yaghi, O. M. Science 2002, 295, 469-472. (b) Eddaoudi, M.; Li, H. L.; Yaghi, O. M. J. Am. Chem. Soc. 2000, 122, 1391-1397. (c) Jhung, S. H.; Lee, J. H.; Yoon, J. W.; Serre, C.; Férey, G.; Chang, J. S. Adv. Mater. 2007, 19, 121-124. (d) Jia, J. H.; Lin, X.; Wilson,
C.; Blake, A. J.; Champness, N. R.; Hubberstey, P.; Walker, G.; Cussen, E. J.; Schröder, M. Chem. Commun. 2007, 840-842. (e) Latroche, M.; Surble, S.; Serre, C.; Mellot-Draznieks, C.; Llewellyn, P. L.; Lee, J. H.; Chang, J. S.; Jhung, S. H.; Férey, G. Angew. Chem.Int. Ed. 2006, 45, 8227-8231. (f) Loiseau, T.; Lecroq, L.; Volkringer, C.; Marrot, J.; Férey, G.; Haouas, M.; Taulelle, F.; Bourrelly, S.; Llewellyn, P. L.; Latroche, M. J. Am. Chem. Soc. 2006, 128, 1022310230. (g) Ramsahye, N. A.; Maurin, G.; Bourrelly, S.; Llewellyn, P.; Loiseau, T.; Férey, G. Phys. Chem. Chem. Phys. 2007, 9, 10591063. (h) Rosi, N. L.; Eckert, J.; Eddaoudi, M.; Vodak, D. T.; Kim, J.; O'Keeffe, M.; Yaghi, O. M. Science 2003, 300, 1127-1129. (i) Rowsell, J. L. C.; Spencer, E. C.; Eckert, J.; Howard, J. A. K.; Yaghi, O. M. Science 2005, 309, 1350-1354. (j) Surble, S.; Millange, F.; Serre, C.; Duren, T.; Latroche, M.; Bourrelly, S.; Llewellyn, P. L.; Férey, G. J. Am. Chem. Soc. 2006, 128, 14889-14896. (k) Yaghi, O. M.; Li, G. M.; Li, H. L. Nature 1995, 378, 703-706.

(6) Maji, T. K.; Mukherjee, P. S.; Mostafa, G.; Zangrando, E.; Chaudhuri, N. R. Chem. Commun. 2001, 1368-1369.

(7) (a) Hagrman, P. J.; Hagrman, D.; Zubieta, J. Angew. Chem.-Int. Ed. 1999, 38, 2639-2684. (b) Halder, G. J.; Kepert, C. J.; Moubaraki, B.; Murray, K. S.; Cashion, J. D. Science 2002, 298, 1762-1765. (c) Kahn, O. Acc. Chem. Res. 2000, 33, 647-657. (d) de Bettencourt-Dias, A Dalton Trans. 2007, 2229-2241. (e) Hong, X. L.; Li, Y. Z.; Hu, H. M.; Pan, Y.; Bai, J. F.; You, X. Z. Cryst. Growth Des. 2006, 6, 12211226. (f) Wang, P.; Ma, J. P.; Dong, Y. B.; Huang, R. Q. J. Am. Chem. Soc. 2007, 129, 10620-10621. (g) Li, F. Y.; Xu, L.; Gao, G. G.; Fan, L. H.; Bi, B. Eur. J. Inorg. Chem. 2007, 3405-3409. (h) Luo, F.; Hu, D. X.; Xue, L.; Che, Y. X.; Zheng, J. M. Cryst. Growth Des. 2007, 7, 851-853. (i) Zhao, B.; Cheng, P.; Dai, Y.; Cheng, C.; Liao-Zheng, D.; Yan, S. P.; Jiang, Z. H.; Wang, G. L. Angew. Chem.-Int. Ed. 2003, 42, 934-936.

(8) (a) Ananias, D.; Paz, F. A. A.; Carlos, L. D.; Geraldes, C.; Rocha, J. Angew. Chem.-Int. Ed. 2006, 45, 7938-7942. (b) Rocha, J.; Anderson, M. W. Eur. J. Inorg. Chem. 2000, 801-818. (c) Cheetham, A. K.; Ferey, G.; Loiseau, T. Angew. Chem.-Int. Ed. 1999, 38, 3268-3292.

(9) (a) Férey, G.; Mellot-Draznieks, C.; Serre, C.; Millange, F. Acc. Chem. Res. 2005, 38, 217-225. (b) Murugavel, R.; Walawalkar, M. G.; Dan, M.; Roesky, H. W.; Rao, C. N. R. Acc. Chem. Res. 2004, 37, 763774. (c) Kim, J.; Chen, B. L.; Reineke, T. M.; Li, H. L.; Eddaoudi, M.; Moler, D. B.; O'Keeffe, M.; Yaghi, O. M. J. Am. Chem. Soc. 2001, 123, 8239-8247. (d) Eddaoudi, M.; Kim, J.; Wachter, J. B.; Chae, H. K.; O'Keeffe, M.; Yaghi, O. M. J. Am. Chem. Soc. 2001, 123, 4368-4369. (e) Eddaoudi, M.; Moler, D. B.; Li, H. L.; Chen, B. L.; Reineke, T. M.; O'Keeffe, M.; Yaghi, O. M. Acc. Chem. Res. 2001, 34, 319-330.

(10) (a) Simperler, A.; Foster, M. D.; Friedrichs, O. D.; Bell, R. G.; Paz, F. A. A.; Klinowski, J. Acta Crystallogr. B 2005, 61, 263-279. (b) Mellot-Draznieks, C.; Girard, S.; Ferey, G.; Schon, J. C.; Cancarevic, Z.; Jansen, M. Chem.-Eur. J. 2002, 8, 4102-4113.

(11) (a) Habib, H. A.; Sanchiz, J.; Janiak, C. Dalton Trans. 2008, 1734 1744. (b) Yang, E. C.; Li, J.; Ding, B.; Liang, Q. Q.; Wang, X. G.; Zhao, X. J. CrystEngComm 2008, 10, 158-161. (c) Liu, Q. Y.; Yuan, D. Q.; Xu, L. Cryst. Growth Des. 2007, 7, 1832-1843. (d) Ma, S. Q.; Wang, X. S.; Manis, E. S.; Collier, C. D.; Zhou, H. C. Inorg. Chem. 2007, 46, 3432-3434. (e) Casarin, M.; Corvaja, C.; Di Nicola, C.; Falcomer, D.; Franco, L.; Monari, M.; Pandolfo, L.; Pettinari, C.; Piccinelli, F. Inorg. Chem. 2005, 44, 6265-6276. (f) Ye, B. H.; Ding, B. B.; Weng, Y. Q.; Chen, X. M. Cryst. Growth Des. 2005, 5, 801806.

(12) (a) Moulton, B.; Zaworotko, M. J. Chem. Rev. 2001, 101, 1629-1658. (b) Hennigar, T. L.; MacQuarrie, D. C.; Losier, P.; Rogers, R. D.; Zaworotko, M. J. Angew. Chem.-Int. Ed. 1997, 36, 972-973.

(13) Soares-Santos, P. C. R.; Cunha-Silva, L.; Almeida Paz, F. A.; Ferreira, R. A. S.; Rocha, J.; Trindade, T.; Carlos, L. D.; Nogueira, H. I. S. Cryst. Growth Des. 2008, 8, 2505-2516.

(14) (a) Shi, F. N.; Cunha-Silva, L.; Ferreira, R. A. S.; Mafra, L.; Trindade, T.; Carlos, L. D.; Paz, F. A. A.; Rocha, J. J. Am. Chem. Soc. 2008, 130, 150-167. (b) Harbuzaru, B. V.; Corma, A.; Rey, F.; Atienzar, P.; Jorda, J. L.; Garcia, H.; Ananias, D.; Carlos, L. D.; Rocha, J. Angew. Chem.-Int. Ed. 2008, 47, 1080-1083. (c) Chelebaeva, E.; Larionova, J.; Guari, Y.; Ferreira, R. A. S.; Carlos, L. D.; Paz, F. A. A.; Trifonov, A.; Guerin, C. Inorg. Chem. 2008, 47, 775-777. (d) Paz, F. A. A.; Klinowski, J. Pure Appl. Chem. 2007, 79, 1097-1110. (e) Girginova, P. I.; Paz, F. A. A.; Soares-Santos, P. C. R.; Ferreira, R. A. S.; Carlos, L. D.; Amaral, V. S.; Klinowski, J.; Nogueira, H. I. S.; Trindade, T. Eur. J. Inorg. Chem. 2007, 4238-4246. (f) Cunha-Silva, L.; Mafra, L.; Ananias, D.; Carlos, L. D.; Rocha, J.; Paz, F. A. A. Chem. Mater. 2007, 19, 3527-3538. (g) Shi, F. N.; Paz, F. A. A.; Girginova, P.; Rocha, J.; Amaral, V. S.; Klinowski, J.; Trindade, T. 
J. Mol. Struct. 2006, 789, 200-208. (h) Paz, F. A. A.; Rocha, J.; Klinowski, J.; Trindade, T.; Shi, F. N.; Mafra, L. Prog. Solid State Chem. 2005, 33, 113-125. (i) Girginova, P. I.; Paz, F. A. A.; Nogueira, H. I. S.; Silva, N. J. O.; Amaral, V. S.; Klinowski, J.; Trindade, T. Polyhedron 2005, 24, 563-569. (j) Paz, F. A. A.; Klinowski, J. J. Solid State Chem. 2004, 177, 3423-3432. (k) Paz, F. A. A.; Klinowski, J. Inorg. Chem. 2004, 43, 3948-3954. (1) Paz, F. A. A.; Klinowski, J. Inorg. Chem. 2004, 43, 3882-3893. (m) Paz, F. A. A.; Klinowski, J. Chem. Commun. 2003, 1484-1485. (n) Paz, F. A. A.; Klinowski, J. J. Phys. Org. Chem. 2003, 16, 772-782. (o) Paz, F. A. A.; Bond, A. D.; Khimyak, Y. Z.; Klinowski, J. Acta Crystallogr. E 2002, 58, M691M693.

(15) (a) Rodrigues, M. O.; da Costa, N. B.; de Simone, C. A.; Araujo, A. A. S.; Brito-Silva, A. M.; Paz, F. A. A.; de Mesquita, M. E.; Junior, S. A.; Freire, R. O. J. Phys. Chem. B 2008, 112, 4204-4212. (b) Soares-Santos, P. C. R.; Paz, F. A. A.; Ferreira, R. A. S.; Klinowski, J.; Carlos, L. D.; Trindade, T.; Nogueira, H. I. S. Polyhedron 2006, $25,2471-2482$

(16) (a) Daiguebonne, C.; Kerbellec, N.; Bernot, K.; Gerault, Y.; Deluzet, A.; Guillou, O. Inorg. Chem. 2006, 45, 5399-5406. (b) He, J.; Zhang, J. X.; Tan, G. P.; Yin, Y. G.; Zhang, D.; Hu, M. H. Cryst. Growth Des. 2007, 7, 1508-1513. (c) Kirillov, A. M.; Karabach, Y. Y: Haukka, M.; da Silva, M.; Sanchiz, J.; Kopylovich, M. N.; Pombeiro, A. J. L. Inorg. Chem. 2008, 47, 162-175. (d) Li, X. H.; Yang, S. Z.; Xiao, H. P. Cryst. Growth Des. 2006, 6, 2392-2397. (e) Serre, C.; Millange, F.; Thouvenot, C.; Nogues, M.; Marsolier, G.; Louer, D.; Ferey, G. J. Am. Chem. Soc. 2002, 124, 13519-13526. (f) Yang, E. C.; Zhao, H. K.; Ding, B.; Wang, X. G.; Zhao, X. J. Cryst. Growth Des. 2007, 7, 2009-2015.

(17) (a) Huang, Y. G.; Jiang, F. L.; Yuan, D. Q.; Wu, M. Y.; Gao, Q.; Wei, W.; Hong, M. C. Cryst. Growth Des. 2008, 8, 166-168. (b) Huang, Y. G.; Wu, B. L.; Yuan, D. Q.; Xu, Y. Q.; Jiang, F. L.; Hong, M. C. Inorg. Chem. 2007, 46, 1171-1176. (c) Liang, Y. C.; Cao, R.; Su, W. P.; Hong, M. C.; Zhang, W. J. Angew. Chem.-Int. Ed. 2000, 39, 3304-3307. (d) Liang, Y. C.; Hong, M. C.; Cao, R.; Weng, J. B.; Sun, D. F.; Su, W. P. Chin. J. Inorg. Chem 2002, 18, 99-106. (e) Liang, Y. C.; Hong, M. C.; Su, W. P.; Cao, R.; Zhang, W. J. Inorg. Chem. 2001, 40, 4574-4582. (f) Liu, C. B.; Li, X.; Li, X. X.; Wen, H. L. Chem. J. Chin. Univ-Chin. 2006, 27, 2256-2259. (g) Qin, C.; Wang, X. L.; Wang, E. B.; Su, Z. M. Inorg. Chem. 2005, 44, 71227129. (h) Song, Y. S.; Bing, Y. Y.; Chen, Z. X. J. Coord. Chem. 2005, 58, 811-816. (i) Song, Y. S.; Yan, B.; Chen, Z. X. J. Mol. Struct. 2005, 750, 101-108. (j) Song, Y. S.; Yan, B.; Weng, L. H. Inorg. Chem. Commun. 2006, 9, 567-570. (k) Yue, Q.; Yang, J.; Yuan, H. M.; Chen, J. S J. Mol. Struct. 2007, 827, 114-120. (1) Zhang, G. Q.; Wang, Q.; Qian, Y.; Yang, G. Q.; Ma, J. S. J. Mol. Struct. 2006, 796, $187-$ 194. (m) Zhang, X. F.; Huang, D. G.; Chen, C. N.; Liu, Q. T.; Liao, D. Z.; Li, L. C. Inorg. Chem. Commun. 2005, 8, 22-26.

(18) Kottke, T.; Stalke, D. J. App. Crystallogr. 1993, 26, 615-619.

(19) APEX-2 Data Collection Software Version 2.1-RC13; Bruker AXS: Delft, The Netherlands 2006.

(20) Cryopad Remote Monitoring and Control, Version 1.451; Oxford Cryosystems: Oxford, United Kingdom, 2006.

(21) SAINT+ Data Integration Engine v. 7.23a; Bruker AXS, Madison Wisconsin.

(22) Sheldrick, G. M. SADABS v.2.01, Bruker/Siemens Area Detector Absorption Correction Program; Bruker AXS, Madison: Wisconsin, 1998
(23) Sheldrick, G. M. SHELXS-97, Program for Crystal Structure Solution; University of Göttingen: Germany, 1997.

(24) Sheldrick, G. M. SHELXL-97, Program for Crystal Structure Refinement; University of Göttingen: Germany, 1997.

(25) (a) Spek, A. L. Acta Crystallogr. A 1990, 46, C34. (b) Spek, A. L. J. Appl. Crystallogr. 2003, 36, 7-13.

(26) Popa, M.; Kakihana, M. Solid State Ion. 2001, 141, 265-272.

(27) Hussein, G. A. M. J. Anal. Appl. Pyrolysis 1996, 37, 111-149.

(28) (a) Hawxwell, S. M.; Brammer, L. CrystEngComm 2006, 8, 473476. (b) Burrows, A. D.; Cassar, K.; Friend, R. M. W.; Mahon, M. F.; Rigby, S. P.; Warren, J. E. CrystEngComm 2005, 7, 548-550. (c) Chen, W.; Wang, J. Y.; Chen, C.; Yue, Q.; Yuan, H. M.; Chen, J. S.; Wang, S. N. Inorg. Chem. 2003, 42, 944-946.

(29) (a) Allen, F. H. Acta Crystallogr. B 2002, 58, 380-388. (b) Allen, F. H.; Motherwell, W. D. S. Acta Crystallogr. B 2002, 58, 407-422.

(30) (a) Cheng, J. W.; Zhang, J.; Zheng, S. T.; Zhang, M. B.; Yang, G. Y. Angew. Chem.-Int. Ed. 2006, 45, 689. (b) Wang, R. Y.; Liu, H.; Carducci, M. D.; Jin, T. Z.; Zheng, C.; Zheng, Z. P. Inorg. Chem. 2001, 40, 2743-2750. (c) Wang, R. Y.; Selby, H. D.; Liu, H.; Carducci, M. D.; Jin, T. Z.; Zheng, Z. P.; Anthis, J. W.; Staples, R. J. Inorg. Chem. 2002, 41, 278-286.

(31) (a) Burgstein, M. R.; Gamer, M. T.; Roesky, P. W. J. Am. Chem. Soc. 2004, 126, 5213-5218. (b) Burgstein, M. R.; Roesky, P. W. Angew. Chem.-Int. Ed. 2000, 39, 549-551. (c) Wang, R. Y.; Song, D. T.; Wang, S. M. Chem. Commun. 2002, 368-369.

(32) Zhang, J.; VonDreele, R. B.; Eyring, L. J. Solid State Chem. 1996, $122,53-58$.

(33) (a) Baburin, I. A.; Blatov, V. A.; Carlucci, L.; Ciani, G.; Proserpio, D. M. J. Solid State Chem. 2005, 178, 2452-2474. (b) Blatov, V. A.; Carlucci, L.; Ciani, G.; Proserpio, D. M. CrystEngComm 2004, 6, 377395.

(34) Delgado-Friedrichs, O.; Foster, M. D.; O'Keeffe, M.; Proserpio, D. M.; Treacy, M. M. J.; Yaghi, O. M. J. Solid State Chem. 2005, 178, 25332554.

(35) Wells, A. F. Structural Inorganic Chemistry, 4th ed.; Clarendon Oxford University Press: New York, 1975.

(36) (a) Blatov, V. A.; Shevchenko, A. P. TOPOS - Version 4.0 Professional (beta evaluation); Samara State University, Samara, Russia, 2006. (b) Blatov, V. A.; Shevchenko, A. P.; Serezhkin, V. N. J. Appl. Crystallogr. 2000, 33, 1193.

(37) Hill, R. J.; Long, D. L.; Hubberstey, P.; Schroder, M.; Champness, N. R. J. Solid State Chem. 2005, 178, 2414-2419.

(38) (a) Deluzet, A.; Maudez, W.; Daiguebonne, C.; Guillou, O. Cryst. Growth Des. 2003, 3, 475-479. (b) Hyde, S. T.; Delgado-Friedrichs, O.; Ramsden, S. J.; Robins, V. Solid State Sci. 2006, 8, 740.

(39) Socrates, G. Infrared Characteristic Group Frequencies - Tables and Charts, 2nd ed.; John Wiley \& Sons Ltd: Baffins Lane, Chichester, 1994.

(40) (a) Deacon, G. B.; Phillips, R. J. Coord. Chem. Rev. 1980, 33, 227250. (b) Oldham, C. Carboxylates, Squarates and Related Species. In Comprehensive Coordination Chemistry, 1st ed.; Wilkinson, S. G., Ed.; Pergamon Press: 1987; Vol. 2, pp 435-459.

(41) (a) Wan, Y.; Ma, J. X.; Fang, M.; Liu, Y. T. J. Rare Earths 2003, 21, 609-612. (b) Putna, E. S.; Vohs, J. M.; Gorte, R. J.; Graham, G. W. Catal. Lett. 1998, 54, 17-21.

\section{CG8004932}

